\title{
LA ESTRUCTURA GEOMÉTRICA DE LOS GRADOS EN EL UNIVERSO DE LOS ESTADOS ESPIRITUALES
}

\section{Eric Winkel}

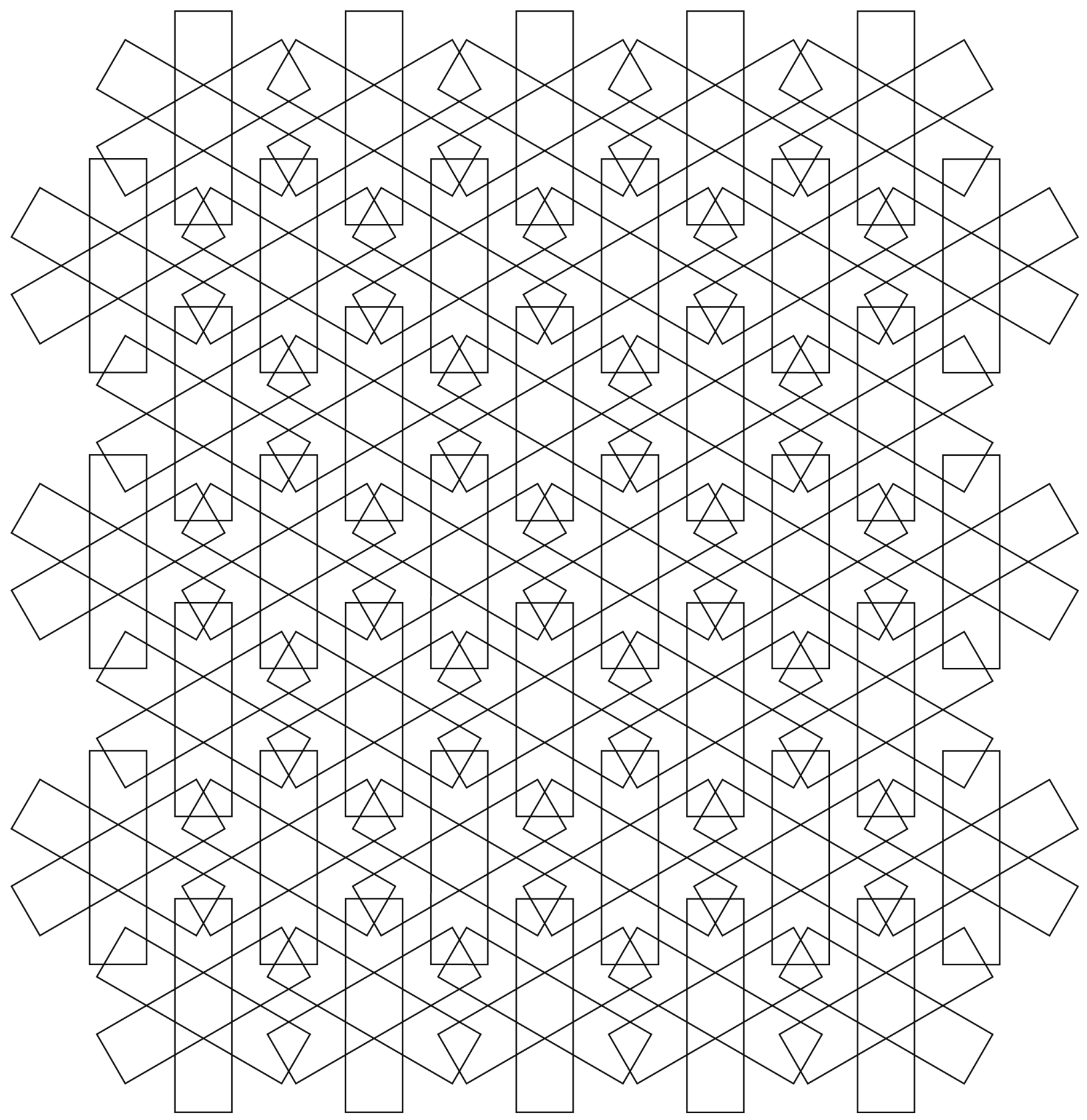




\section{ANTEGEDENTES}

La obra al-Futūhăt al-makkīya ("Las iluminaciones de La Meca"), las revelaciones que Ibn al-'Arabī recibe y desarrolla en La Meca, es una de las mayores obras de la civilización occidental. Compuesta por unas diez mil páginas, su tamaño ha supuesto por sí solo un obstáculo para el público. La primera edición crítica completa se publicó en 2010 y una segunda edición de El Cairo en 2013² . Las traducciones únicamente han abarcado alrededor del uno o dos por ciento del total de la obra. Como traductor, he estado trabajando desde 2002 en la primera traducción completa de al-Futūhāt al-makkīya, cuya edición ya ha comenzado.

Aun siendo considerado uno de los textos más oscuros y densos sobre el islam y el mundo espiritual, al-Futūhāt al-makkīya se escribió para ser comprendido, e Ibn al-'Arabī alienta constantemente al público a aprender y comprenderlo, y lo que es aún más importante, a comprobar por uno mismo (el término que utiliza es tahqīq, de la raíz de haqq, la verdad). No se trata, en absoluto, de un trabajo puramente intelectual, y su comprensión no se consigue solo a través del pensamiento y del análisis. Ibn al-'Arabī deja muy claro que todo lo que transmite ya ha sido probado, y este término, dawq, es el modo de comprensión de aquellos que comprueban por sí mismos. En el Capítulo 72, Ibn al-'Arabī interpreta el contexto de las "155 preguntas" que al-Ḥakìm al-Tirmidī formuló con la intención de que fuesen indescifrables, a modo de cuestiones de análisis que sirviesen para diferenciar a aquellos que prueban las realidades de los intelectuales que piensan y analizan, pero no prueban.

Ibn al-'Arabī declara a su público que el contenido de su obra es el resultado de una revelación que tuvo en La Meca, y que los 560 capítulos de Futühät surgieron como luz y se grabaron como luz (literalmente se foto-grafiaron), a través del cuerpo sutil del Joven Caballero que se le apareció mientras circunambulaban la Caaba. Esta visión incluía números.

¿Cómo entenderemos los diferentes números que aparecen a lo largo de la obra? En algunos ejemplos Ibn al-'Arabī habla de números y ofrece sus contextos aritméticos. Por ejemplo, en su debate acerca de los elementos numéricos del número cuatro, nos conduce a través de una cualidad numérica:

[Esto se debe a] que las bases de los números son "cuatro". La base tres que está en la cuatro, con la cuatro, hacen siete. La dos en la siete, con la siete, hacen nueve. La uno en la cuatro, con la nueve, hacen diez. Basándose en lo anterior, se puede componer como se prefiera, pero no se encontrará un número completo excepto en el caso de la base seis, ya que en ella se encuentra la mitad, la sexta, y la tercera. ${ }^{2}$

1 Para más información acerca de la nueva edición crítica, véase Eric Winkel [enero 2013], Review of 'Abd al-'Azīz Sulțān al-Manșūb (ed.): al-Futūhāt al-makkīya, en fournal of Islamic Studies (Oxford), vol. 24:1:80-82. Las citas de este artículo pertenecen a la segunda edición, 2013, El Cairo (Consejo Superior de Cultura).

2 Es decir, la mitad de 6 (3) más un sexto de seis (1), más un tercio de seis (3) igual a 6. Del Capítulo 2 1:217.8-11 (2013). 
En algunos fragmentos, Ibn al-'Arabī representa un proceso de alif multiplicado por alif, que también describe como 1 multiplicado por 1. En la primera aparición, escrita de su propia mano en el margen, hay una marca que señala que el extraño enunciado anterior es correcto; él sabía claramente que no estaba presentando una aritmética típica. De hecho, en uno de mis trabajos muestro que el proceso en el que 1 al cuadrado da dos resultados diferentes, dependiendo de con qué 1 se empiece, es un proceso no-comunicativo y que dicho proceso únicamente fue resuelto de forma sistemática en el siglo XIX por Hermann Grassman y, más a fondo, por William Kingdon Clifford. Se trata de un álgebra geométrica, también llamada álgebra de Clifford ${ }^{3}$. La visión que Ibn al-'Arabī tiene de este proceso no-comunicativo del producto vectorial es internamente consistente y anima tanto al lector como al traductor a profundizar aún más y a comprobar por sí mismo.

\section{GRADOS}

La obra Futūhāt está dividida en seis secciones, y la segunda sección (capítulos 74-188) trata de las interacciones ( $m u$ 'ámalāt $)$ que suceden entre la criatura y el Creador. Se trata de estados y estaciones que el viajero experimenta y alcanza en el camino espiritual, tales como volverse al perdón, abandonar la sociedad humana y estar satisfecho con Dios. En dieciséis ocasiones en esta segunda sección, Ibn al-'Arabī menciona que hay un número de grados que uno de cada dos o cuatro grupos de viajeros puede alcanzar en estas dieciséis experiencias. Los números se presentan sin ninguna introducción y no hay contextualización matemática. Encontramos solo un ejemplo de desacuerdo en los manuscritos: para lo que resulta ser el número base crucial, algunos manuscritos hablan de 53 mientras que otros hablan de 58. No existen notas al margen acerca de estos números, ni indicación de cómo debe interpretarlos el lector. La primera serie de números se proporciona para el primer estado o estación, el de volverse al perdón, que corresponde a la palabra tawba. Ibn al-'Arabī dice:

La tawba, que tiene lugar en la existencia [en comparación con la divina], se encuentra en el Reino y en los mundos imaginalest, según la mayoría; es la ocasión para unirse en el acuerdo. Algunos de ellos añaden que la tawba se encuentra también en el mundo de lo divino (malakūt). Aquellos que no creían que se encontrara en el malaküt argumentaban que otorga 808 estaciones a la persona que tiene la tawba. Por otro lado, aquellos que creían que se encontraba en el malaküt, afirmaban que otorga 413 estaciones. Aquellos que se detienen a aprender, los expertos de esas paradas donde se aprende, tales como Muhammad Ibn 'Abd al-Ğabbār al-Niffarī y Abū

3 Véase "Gut bacteria and geometric algebra: Finding referents to translate visions described in the Futūhāt alMakkīyah," 7MIAS 54, Diciembre (2013).

4 El mundo divino es el malakūt, el mundo medio del barzah (el mundo de los sueños y la imaginación) es el ǧabarūt, y mulk es el reino del mundo físico percibido por los sentidos físicos. 
Yazīd al-Bisțāmī, afirman: "[La tawba] se encuentra en el reino oculto y sus efectos se producen en el mundo físico." ${ }^{5}$

Muchos de los capítulos de esta sección están emparejados, y el capítulo que sucede al de la tawba es "El abandono de la tawba". Luego, el siguiente capítulo trata de la muğăhada, una de las formas de la palabra ğihād. Éste es el siguiente ejemplo de números de grado, de ahí que lo consideremos junto a los anteriores 413 y 808. Aquí, Ibn al-'Arabī aplica su comprensión de que, en última instancia, los af ${ }^{\prime} a l$, es decir, las actividades, acciones o verbos, pertenecen a Dios. Por consiguiente, no existe dualidad en el gíhād, puesto que la acción de luchar o pelear consiste en oponerse a otra acción, y ambas pertenecen a Dios.

Y puesto que el motivo de la ğiha âd son las conductas originadas en aquellos contra quienes se nos ha dicho que luchemos esforzándonos en el ğihăd, y dado que dichas conductas son acciones [verbos] de $\operatorname{Dios}^{6}$, nosotros solo lucharemos en Él, no contra el enemigo. De hecho, no hay enemigo contra el que combatir, si no es a través de los verbos. De igual modo, luchamos en Él, pues como explica mediante Sus palabras: "cuando luchamos en Él, Él nos guiará hacia Sus caminos; dicho de otra manera, Él nos develará los caminos a seguir [de comportamientos, verbos] y nosotros los tomaremos. De esta manera, nosotros no vemos a otro cuando combatimos.

Por otro lado, y siguiendo con este mismo fragmento, Ibn al-'Arabī es consciente de la gran extensión del libro y reconoce que debe intentar en todo momento condensar, resumir y acortar su descripción. Ibn al-'Arabī visualizó estructuras que le ofrecieron números, y un modo de traducir y transmitir estos números es a través de lenguajes esquemáticos, geométricos y matemáticos. Si podemos definir estos números y su geometría como una matriz, conseguiremos estar en armonía con el autor de esta inmensa y compleja obra.

Os he hablado con claridad con el objetivo de diferenciar los estados de las personas de los combates (muğăhidāt), que son muğăhidūna [personas que luchan en el ğihād d. El debate sería mayor si se dieran detalles en este capítulo. Pero este libro es inmenso, y si tuviéramos que mencionar lo que cada capítulo exige de nosotros, no tendríamos tiempo suficiente para escribirlo. En realidad, tiene que ser resumido para que podamos restringir lo que transcurre en cada capítulo a la corriente de las matrices, nada más. Cada matriz es una alegoría de Eva con la descendencia de Adán, porque todos

5 Capítulo 74, 5:92.18-21.

6 Ibn al-'Arabī sostiene que los verbos y acciones, af'āl, pertenecen al hacedor y actor (fā $i l)$, que únicamente puede ser Dios. De este modo, el fragmento "No digáis nada, yo soy el hacedor que lo hará mañana, a menos que Dios lo desee" (C. 18:23-24) está relacionado con "Complace a tu Señor en todo aquello que desee" (C. 11:107). 
ellos son sus hijos, cada uno de ellos. Si Dios solo me diera un libro divino, yo publicaría [110] todo el contenido que abarcase este libro, de forma exhaustiva, en un único pedacito de papel, así como el Mensajero de Dios - la paz y las bendiciones sean con él- sacó dos libros de sus manos. Uno de ellos, era un libro divino, en el que ningún ser creado ha puesto la mano, y declaró que en el libro de su mano derecha estaban los nombres de las personas del Jardín, el nombre de sus antepasados, de sus tribus y de sus familiares, desde el comienzo de su creación hasta el Día del Juicio. Y el otro libro, de igual modo, tenía los nombres de los miserables. Si esto apareciese en un libro convencional, juna ciudad no sería lo suficientemente grande para abarcar sus páginas! Si esto me ocurriese a mí, habría publicado todo un libro ¡en una sola frase! Yo he visto este cuaderno [divino] y aparecía representado como el Jardín en el medio de una portada, y el Fuego [en la otra portada], con una imagen del cielo en un espejo [convexo y esférico].

Dicho lo anterior, Ibn al-'Arabī nos facilita los números de los grados de esta estación de muğăhada. Afirma:

A continuación, vamos a analizar las estaciones que tiene esta cualidad de la muğāhada, que son, en otras palabras, grados de ascenso escalonado y estaciones donde, aquellos a quienes corresponden esos grados, "descansan", y estos son los malāmīya. Existen dos tipos de malāmìya: por un lado, la gente de la cortesía espiritual que se detiene ante un límite y, por otro, la gente de la intimidad y la conexión. Y del mismo modo por lo que respecta a los ‘̄rifün en esta modalidad, que también son de dos tipos: la gente de la cortesía que se detiene ante un límite, y la gente de la intimidad y la conexión. Y esto ocurre en cada una de las estaciones. Lo que le corresponde a los malāmīya, para el tipo de gente que tiene cortesía y se detiene ante los límites, son 58 escalones $^{7}$. De hecho, evoqué la cita donde escuché a Dios hablar de los escalones en su excelencia comparativa ${ }^{8}$, por lo que seguí las palabras de Dios, y ésa es nuestra prioridad. A los malāmīya (aquellos dotados de intimidad y conexión) les pertenecen 453 de los escalones de este capítulo. De igual modo, a los 'arifiūn (los dotados de intimidad y de conexión) les pertenecen 484 escalones. Y por lo que respecta a la gente de cortesía y a quienes se detienen ante los límites, entre los ârifün, les corresponden 89 escalones, o dicho de otra manera, 90 menos 1, que es la diferencia entre los escalones de los nombres divinos, que son 10 (es decir, 99-10=89). ${ }^{9}$

7 En los tres manuscritos, el número es 53.

8 Osman Yahya sugiere que esta declaración se basa en dos versos: faddal Allāh al-muǧahidīna (C. 4:95) y a żamu darağatan (C. 9:20).

9 Capítulo 76, 5:109.7-110.15. 


\section{FUNGIONES ITERATIVAS}

Con el objetivo de construir la estructura de los grados de las estaciones, comenzamos con la idea de las matrices. Ibn al-'Arabī sostiene que la estructura que muestra el número de grados se genera, al igual que un bebé en el útero, paso a paso ${ }^{10}$. En el siguiente fragmento, Ibn al-'Arabī describe la generación en espiral de las letras en el instrumento que las produce (el cuerpo humano). Dice:

En cuanto a los términos, "su órbita" y "el movimiento radiante de su periodo de tiempo", nos referimos a la órbita mediante la cual se genera la parte corporal que nos revela la letra. La cabeza del ser humano fue revelada por Dios con un movimiento orbital particular y un cuerpo orbital particular de una línea orbital particular. Y el cuello pertenece a la órbita que limita con la órbita mencionada, y el pecho procede de la cuarta órbita dentro de esa primera órbita que hemos mencionado. De este modo, todo lo que aparece en la cabeza, de significados, espíritus y secretos, así como las letras y sus ejes, y todo aquello que la cabeza dota de forma y significado, proviene de esa órbita. Su recorrido es de 12000 años, y lo que tiene de forma y significado, y las letras (que son totalmente redondas) tienen 11000 años. El recorrido de la órbita del pecho, con la propiedad que citamos, es de 9000 años. Su naturaleza, su elemento y lo que proviene de él, vuelve a la verdad de la órbita. ${ }^{11}$

Estas órbitas repetitivas son espirales que gradualmente van aumentando de círculos bidimensionales a formas tridimensionales. En realidad, el uso que Ibn al-'Arabī le da a la palabra "volumen" (hayyiz) viene de tahayyaza, que es el movimiento que hacen las serpientes al enroscarse, y se define clásicamente a partir de un poema en el que se representa a una anciana alejándose, fuera del alcance de la vista, para no ofrecerle su hospitalidad a un extraño. De este modo, la matriz o estructura-madre es una órbita en espiral que se crea mediante iteraciones.

10 En uno de los fragmentos, Ibn al-'Arabī concreta que no describe los detalles del desarrollo del feto, y que los seres angelicales supervisan cada etapa, para evitar que el libro fuese demasiado extenso.

11 Capítulo 2, 1:283.5-12. 
A continuación, tomamos las correspondencias entre el qutb, los seres espirituales (el eje del universo), y el alif (el signo gráfico que, en realidad, no es una letra, según Ibn al-'Arabī). ${ }^{12}$

La estación vertical del Eje junto con nosotros es la fuerza vital de "Aquel que es autónomo y se mantiene a sí mismo, haciendo que otros subsistan" (cf., al-hayy al-qayyum). Esta es la estación vertical del Eje, singularizada para él, y él fluye con su energía espiritual (himma) a través de todo el universo. De igual manera, el alif fluye en cada dirección [dimensión], incluyendo la dirección del ser espiritual $(r \bar{u} h \bar{a} n \bar{y} y)^{13}$, que nosotros percibimos y que otros no perciben. Con respecto a su corriente, es algo semejante a una respiración, desde el lugar más lejano de salida, que es el espacio desde donde enviamos el aliento, hasta la última parte de la tráquea, y aún se extiende hasta el exterior tras quedarte en silencio. Es lo que conocemos como eco [onda sonora]. Esto es la "autosuficiencia" (qayyümīya) del alif, que no consiste solo en que se "mantiene". ${ }^{14}$

Seguidamente, Ibn al-'Arabī nos hace considerar los generadores de estas letras, que son también estaciones: los Amigos (awliya $\bar{a}$ ) a los que Dios pone a cargo del universo. Hay Amigos que son determinados por números y otros que no. Tendremos en cuenta a los primeros.

Sé consciente de que Dios nos ayuda, tanto a nosotros como a ti, con un espíritu que proviene de Él, y este capítulo abarca los tipos de Hombres que son determinados por números, y aquellos que no lo son, así como abarca temas que no son llevados a la práctica excepto por las criaturas más distinguidas de Dios, aquellas que en su época corresponden a los profetas en los períodos de la profecía. Ésta la profecía universal [a diferencia de la profecía legisladora, cuya puerta está cerrada, ya que no hay profeta después de mí (de Muhammad)]..$^{15}$

12 Para más información, véase "Alif is not a letter and 1 is not a number," ("Alif no es una letra y el 1 no es un número"), Eric Winkel, academia.edu

13 Los seres espirituales son las letras arquetípicas y los guardianes celestiales que dominan el universo.

14 Capítulo 2, 1:274.8-11.

15 Capítulo 73, 4:269.16-18. 
ISSN: 2341-1368

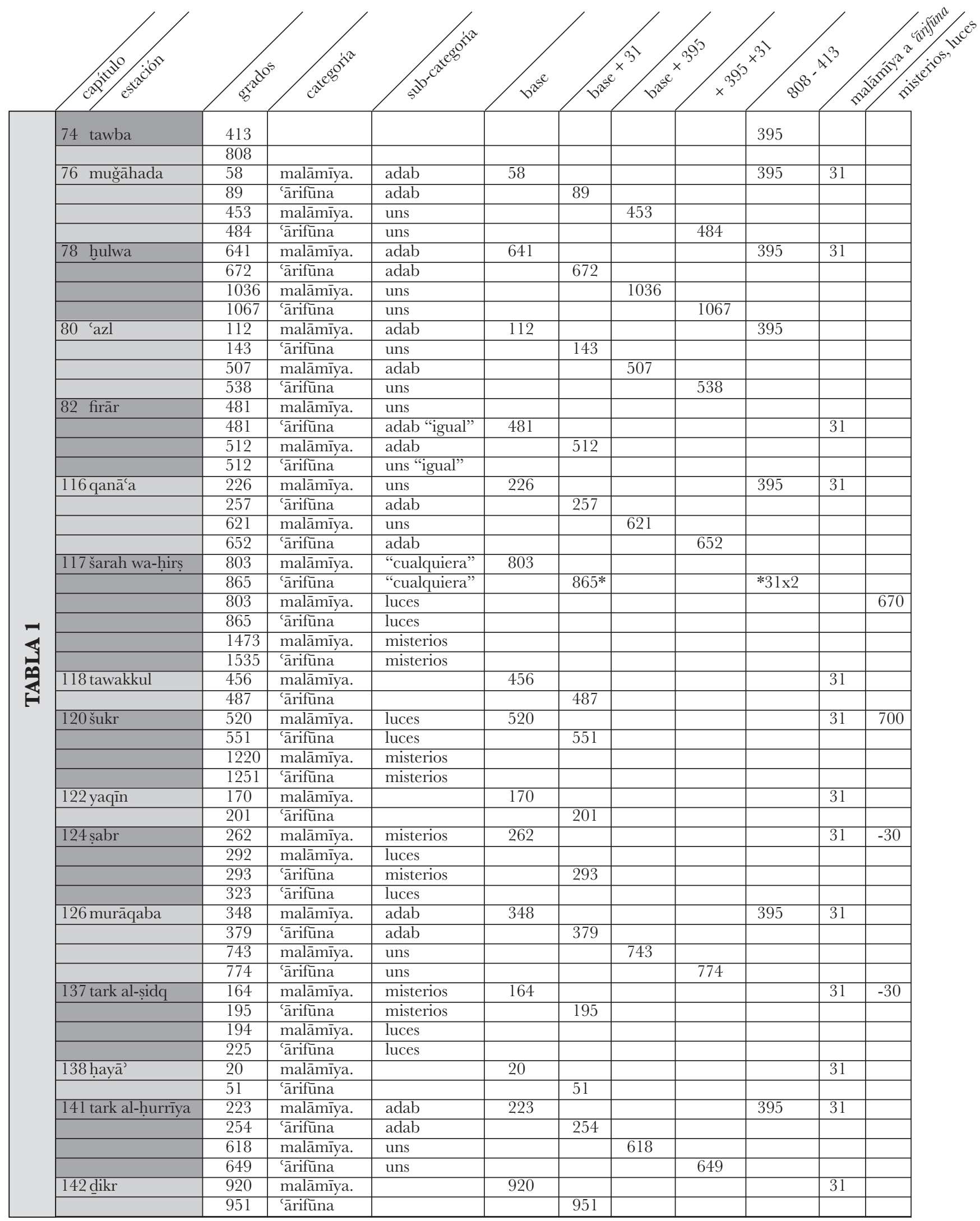




\section{LOS NÚMEROS}

\section{1}

Para analizar la Tabla 1, comenzaremos con el número 31. Este número es la diferencia entre los malāmīya y los 'ârifün. La clave de esto se desarrolla como sigue:

Ellos se protegen a sí mismos de ellos mismos, por lo que ¡no se reconocen ni a ellos mismos! Están en las áreas ocultas de lo oculto, escondidos tras cortinas. Son los danāin, [en realidad, Dios tiene seres especiales en Su creación y Él los alimenta con Su bondad], los Verdaderos, aquellos escogidos (únicamente para Él); se alimentan de comida y van a los mercados, ocultándose y con la comida escondida. Este es el estado de esta categoría de espiritualidad, citado en este capítulo. $^{16}$

$\mathrm{Al}$ esconderse de ellos mismos, se les niega cual-

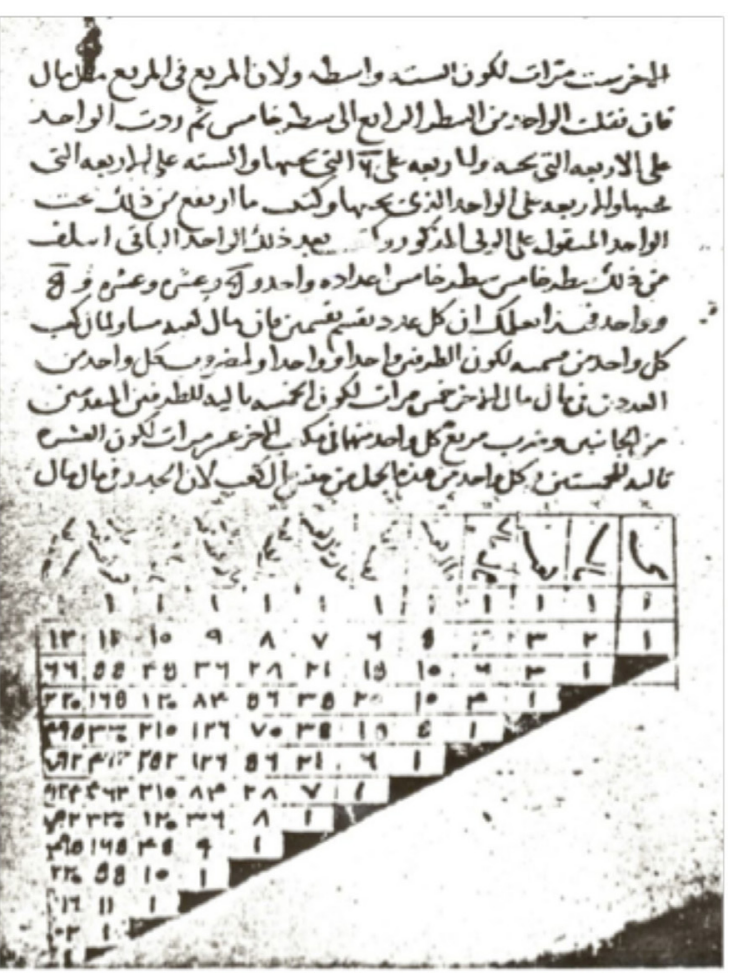
quier conocimiento que los cinco sentidos les pudieran proporcionar. Sin embargo, el número 5 no es correcto aquí: tenemos que considerar el 5 en el ámbito de la combinatoria, y más concretamente, de qué manera los 5 sentidos interactúan para obtener información y conocimiento. De este modo, no solo tenemos los cinco sentidos, sino también sus distintas combinaciones, como vista y oído, o vista-oído-gusto. Con la combinatoria, nos introducimos en la estructura conocida convencionalmente como el triángulo de Pascal, explicado así:

Para la fila 5 tenemos, específicamente, 1510105 1. En el sistema de álgebra de Clifford, o el álgebra geométrica, esta fila expresa 1 valor escalar, 5 líneas, 10 volúmenes, 5 hipervolúmenes y 1 estructura de cinco dimensiones, que se da cuando los cinco sentidos están activados para una misma información. Así es como nosotros conseguimos el 31, al que no tienen acceso los malāmīya; en cada ejemplo de grados, los ārifün tienen 31 grados más que los malāmīya.

16 Es decir, en el Capítulo 23, sobre los malāmīya, 1:555.5-7. 


\section{8}

Ibn al-'Arabī trabaja con 28 letras del alfabeto árabe. El autor percibe las letras como volúmenes, es decir, como elementos tridimensionales. Fijémonos en los volúmenes de distintas estructuras hiperdimensionales en el siguiente gráfico.

\begin{tabular}{cccc} 
& multiplicado por & volúmenes & dimensión \\
\hline 28 & 2 & 56 & 8 \\
\hline 28 & 3 & 84 & 9 \\
\hline 28 & 13 & 364 & 14 \\
\hline 28 & 20 & 560 & 16 \\
\hline 28 & 55 & 1540 & 22 \\
\hline 28 & 117 & 3276 & 28 \\
\hline
\end{tabular}

Es decir, en una estructura con 28 dimensiones, hay 3276 volúmenes; y el número de letras multiplicado por 117 es 3276 .

\section{5}

La diferencia entre la gente con cortesía que se detiene ante los límites y la gente de intimidad y conexión es siempre de 395. Así, para los grados de la tawba, la diferencia entre ambos es de 395. Es decir,

$808-413=395$

Base: 20

La matriz y la composición de esta base no me quedan claras. Sabemos que Ibn al-'Arabī es totalmente conocedor de los 560 números de los capítulos de Futūhăt, tanto como de su fecha de nacimiento. 560 dividido entre el número de letras, 28, es 20.

Base: 58

El 58 sirve como base para muchos de los grados. La propia composición de su matriz parece ser 28 y 30. El lugar del 30 en esta base y en el 262 (véase más abajo) es algo confuso para mí. ${ }^{17}$

Base: 112

El 112 sirve como base para el 170 (véase más abajo) y está compuesto de la siguiente manera: 28282828

Base: 164

El 164 está compuesto por las tres bases siguientes: 58582820

17 Nótese que he trabajado con estos números durante dos años. 
Base: 170

El 170 está compuesto por las 2 bases siguientes: 5828282828

Base: 223

Para el 223, utilizo dos números, el 7 y el 14, que aparecen de nuevo en el 520 (ver más abajo), y que son factores del 28: 58585828147

Base: 226

El 226 está compuesto por las dos bases siguientes: 58282828282828

Base: 262

El 262 está compuesto por dos bases, con la aparición del 30 aquí y en cada 58: 5858585830

Base: 348

El 348 está compuesto por la siguiente base: 585858585858

Base: 413

El 413, que sirve como base para algunos números, procede de la tawba, y está emparejado con el 808. La diferencia entre 808 y 413 es 395, que es el número de grados no alcanzados por los que "se detienen ante los límites". Los dotados de intimidad y conexión obtienen 395 grados.

En la Tabla 2 debemos tener en cuenta la matriz de los generadores, los Amigos (awliy $\bar{a}$ ) que están a cargo de la creación, encomendados por sus Amigos (walī, un nombre de Dios). Estos Amigos, que están "vallados por números", suman 590 en total. Cada uno genera acciones (y grados) entre las 28 letras, con un total de 16520. Esta suma dividida entre 40 partes es igual a 413.

Base: 456

El 456 está compuesto por las dos bases siguientes: 585858582828282828282828

Base: 481

El 481 está compuesto por tres bases, y la primera base (de menor a mayor) utiliza el 413 de la tawba. Los dos veintes pueden entenderse como 40, que es el valor escalar de mìm, asociada normalmente con la humanidad. En cualquier caso, la composición puede ser la siguiente: 413282020

Base: 520

El 520 puede componerse de la siguiente manera: 4135828147

Base: 641

El 641 puede estar compuesto por las tres bases siguientes: 413585828282828 
Base: 803

Ésta se compone en realidad de dos estaciones distintas, šarah y hirṣ. Sin embargo, mientras la distancia entre malāmìya y ârifün es dos veces el 31 (por consiguiente, sabemos que la cifra es el doble de 31), el 803 debe entenderse como un todo (ya que $803 / 2$ no es un número contable). La composición utiliza la base anterior de 223, y puede ser la siguiente: 22358585858585858585858

Base: 920

El 920 puede estar compuesto por dos bases. La base 808, que está compuesta a su vez por la 413 y la 395, proviene de la estación de la tawba: 80828282828

\section{MISTERIOS Y LUGES}

Hay cuatro ejemplos de misterios y luces: dos con misterios, sin luces, que son 670 y 700, y los otros dos ejemplos son 30 negativo (-30). A continuación, Ibn al-'Arabī asocia șabr con șazm, como en $L a$ oración es una luzy la paciencia es una iluminación, es decir, el ayuno ${ }^{18}$. En este caso, debemos observar que sabr tiene una iluminación en su composición, por lo que los misterios sin las luces son 30 menos. Parece que el 30 podría ser una base para todos los ejemplos. Dejando esto a un lado, estas cifras son algo confusas para mí.

\section{TABLA 2: LA MATRIZ}

\section{0 areliy $\overrightarrow{a^{3}}$}

Los awliy $\bar{a}^{\prime}$ generan las 28 letras, y hay 590 awliy $\bar{a}$. Las primeras líneas del poema de abajo (que encabeza el Capítulo 74 como introducción a los "Amigos tomados en cuenta") mostrarán como Ibn al-'Arabī percibe la relación entre estos Amigos y las letras. El maestro habla del alif y del qutb al igual que lo hace de las personas, con distinto género, personalidad y función. Las letras gramaticalmente "débiles" son el 1+2, el qutb + imāmān, el alif wāw ya . En este caso, he escogido el Palacio de los Recuerdos como técnica para memorizar un gran número de elementos inconexos. Consiste en crear un recorrido mentalmente en un entorno familiar (una construcción con distintas habitaciones o un viaje diario al trabajo) y situar cada elemento en conexión con un punto de referencia familiar. Para Ibn al-'Arabī estos "elementos" ya se conocen, se han observado y se ha interactuado con ellos.

Los ángeles de Dios vienen a nosotros para darnos éxito con un anuncio verdadero.

Ellos hablan de alguien protegido del error, conocido sin duda, libre de la confusión de las suposiciones.

18 Capítulo 71, 3:541.5. 


\begin{tabular}{|c|c|c|c|}
\hline 1 & quț & 28 & \\
\hline 2 & imāmān & 56 & \\
\hline 4 & awtād & 112 & \\
\hline 7 & abdāl & 196 & \\
\hline 12 & nuqabā & 336 & \\
\hline 8 & nuğabā' & 224 & \\
\hline 1 & hawāriyūn & 28 & \\
\hline 40 & rağabiyūn & 1120 & \\
\hline 1 & hatm & 28 & \\
\hline 300 & qalb ādam & 8400 & \\
\hline 40 & qalb nūḥ & 1120 & \\
\hline 7 & qalb ibrāhīm & 196 & \\
\hline 5 & qalb ğibrīl & 140 & \\
\hline 3 & qalb mīkāì̄l & 84 & \\
\hline 1 & qalb isrāfil & 28 & \\
\hline 10 & gayb & 280 & \\
\hline 18 & zāhirūna & 504 & \\
\hline 8 & quwwa/līnā & 224 & \\
\hline 5 & quwwa/līnā & 140 & \\
\hline 15 & hanān & 420 & \\
\hline 4 & hayba & 112 & \\
\hline 24 & fath & 672 & \\
\hline 7 & 'alī & 196 & \\
\hline 21 & asfal & 588 & \\
\hline 3 & imdād & 84 & \\
\hline 3 & raḥmāniyūn & 84 & \\
\hline 1 & istițāla & 28 & \\
\hline 1 & murakkab & 28 & \\
\hline 1 & raqāiq & 28 & \\
\hline 1 & rafrafa & 28 & \\
\hline 2 & ganī & 56 & \\
\hline 1 & yatakarrar & 28 & \\
\hline 10 & taḥīim & 280 & \\
\hline 12 & budalä & 336 & \\
\hline 5 & ištiyāq & 140 & \\
\hline 6 & ayyām & 168 & \\
\hline \multirow[t]{2}{*}{590} & $\mathrm{x} 28$ & 16520 & 413 \\
\hline & & $40=413$ & \\
\hline
\end{tabular}

18 vienen a nosotros abiertamente, y después, vienen 10 escondidos. ${ }^{19}$

8 son los poderosos, los severos, y 5 de ellos son los poderosos en la facilidad. ${ }^{20}$

$\mathrm{Al}$ principio nos abrimos a 14, y más arriba, sus 7 asociados. $^{21}$

Y el $15^{\circ}$ en una vida fácil ${ }^{22}$, y el cuatro, para cubrir los párpados ${ }^{23}$.

Y con respecto al $21^{24}$, se nos hace descender desde la posición [más elevada], a través un país seguro, tranquilo ${ }^{25}$.

19 "Los Hombres que manifiestan la orden de Dios basada en la orden de Dios", cuyo verso es "En realidad, los he llamado en voz alta" (C. 71:8), y "Los Hombres de lo Oculto, y son diez; Ellos solo susurran" (Capítulo 74, 4:291).

20 Ocho Hombres conocidos como los Hombres del poder divino, sus versos proceden del libro de Dios "Duro contra los ingratos" (C. 48:29), y Cinco Hombres... en los pasos de los ocho del poder, a menos que tengan una facilidad que los ocho hombres no tienen" (4:294).

21 Éstas son las catorce letras que abren algunas azoras del Corán, como alif lām mìm. La siguiente categoría, descrita en el Capítulo 2 (1:226), incluye siete de las catorce letras.

22 Las quince almas que son "Hombres de la gentileza que se inclinan ante el afecto divino" (4:295.3).

23 Para "cubrir los párpados": tatbīq se asocia con "El agua cubrió la faz de la Tierra" (Lane), y bajar los párpados está relacionado con la pesadumbre y la dignidad. Uno de estos cuatro versos es allad̄ halaqa sab'a samāwātin tibāqan (C. 67:3), en el que tibāaqan es aquello que se extiende sobre la Tierra "como si se tratara de un tabaq, una cubierta" (Lane).

24 "Entre ellos, Dios está agradecido con sus veintiuna almas, los Hombres por debajo de lo más bajo" $(4: 298)$.

25 Es decir, degradado del ahsan taqwīm. La expresión al-balad al-amìn es también de C. 95:3-4. 
Extendemos nuestras sombras para formar un velo, el ofrecimiento de una rama ${ }^{26}$, sobre la gente, en afecto y naturalidad ${ }^{27}$.

Una oración de los mušrikūn tiene un silbido ${ }^{28}$ de tres puntas $[t \bar{a}]^{29}$; ella me endulza en mi religión.

Y uno de ellos creció en altura y luego se abalanzó con fuerza ${ }^{30}$, y otro de ellos giró, tomando como centro la vena-vital ${ }^{31}$.

\section{ANÁLISIS DE LAS ESTAGIONES}

Lo que viene a continuación son fragmentos de los capítulos de Ibn al-'Arabī que contienen estaciones numeradas. Nos ofrecen una visión de cómo podemos experimentar algunas de estas estaciones Como en los siguientes subcapítulos.

\section{$\boldsymbol{T a r b b a}^{32}$}

Capítulo 74, 5:84.5-14

El reconocimiento [de la ofensa] es un giro de arrepentimiento de aquellos que comprueban por sí mismos y, de este modo Dios, la Verdad, lesabre su pecho $^{33}$.

26 En Lisān al-'arab, wa-mā gasana-k 'annī, "No me ofrezcas una rama", es sinónimo de mā šagalak, "No te ocupes de mí". La gente de la estación (4:298) son hombres y mujeres que "corren" (la sāy de Hajar en busca de agua para su hijo) para abordar las necesidades de los demás.

27 Ellos estrechan sus manos con las personas dotadas de "afecto, naturalidad y bondad" (4:298).

$28 \mathrm{Su}$ "salāt de la Casa está solo silbando y haciendo palmas con las manos" (C. 8:35). Ellos son "tres almas" (4:299).

29 La de tres puntas (mutallata) es el " $t a \bar{a}$ ” de tres puntos". El Mutallita es también el triángulo de tres lados. Uno de los aspectos de estas personas es que poseen un tercer sistema de creencias "entre dos sistemas de creencias".

30 Es un único Hombre, "y ella puede ser una mujer", que se ha "abalanzado y ha crecido de alto" en de buena manera, bien conocida (4:300). La "altura" procede del verso "Él ha crecido en altura sobrepasando a todo excepto a Dios", junto al verso, "Él es contundente sobre Sus criaturas" (C. 6:18).

31 La vena vital, watīn, del Profeta es lo que Dios cortaría si el Profeta hubiera inventado un dicho atribuyéndoselo a Él, y "el que se gira" es alguien que desconoce estas matrices: la relación trascendente, la relación limitada, la relación comparada (de la criatura con el Creador), y una ma rifa que "te ofrece la estación entre las dos estaciones, es decir, tu 'ayn, no el wuğ̌ud de tu 'ayn, ya que el wuğüd de tu 'ayn es el wuğ̌ud del Verdadero, por lo que no está relacionado contigo. Cualquiera que no conozca estas matrices es un munharif (que se aparta) (4:275).

$32 \mathrm{El}$ campo semántico del término tawba comienza con el significado de girar, volver: "originalmente, él regresó a Dios, de la desobediencia a la obediencia" (Lane).

33 Como en a-lam našrah la-ka șadra-ka, “¿Acaso no hemos abierto vuestro pecho?” (C. 94:1). 
Dios está muy satisfecho con aquel que se opone a Él, y está igual de satisfecho con el que acepta Su orden.

¿Por qué es tan frecuente que se conceda Su oferta, especialmente cuando se admite su secreto?

Desde Su propia gracia, Él concede al que se opone exactamente lo que concede a aquel cuyo apoyo desconoces.

Dios puede ayudarnos a nosotros y a ti, dice: "Acude a Dios por completo, tú que eres fiel, de modo que puedas conseguir la felicidad" 34 . De esta manera, Él ordena hacer la tawba a Sus criaturas. A continuación, Él les enseña cómo defenderse en caso de enfrentarse a Él. Él, alabado, sea: "Entonces Él se volvió hacia ellos ${ }^{35}$ para que ellos pudieran volverse [hacia Él, con arrepentimiento]"36, para que pudieran responder, cuando se les considere responsables de ello (i.e., ¿Por qué no te giras con arrepentimiento?): [ellos responderían] "Si Tú te vuelves a nosotros, nosotros nos volveremos a ti." Es como Su palabra, alabada sea: “(Oh, tú ser humano,) ¿qué te ha cautivado de tu Señor, el más Generoso?”37. A lo que el ser humano respondería: “`Vuestra amable generosidad lo hizo!”

Este tipo de cosas sirve al adversario de alegato para su defensa, de manera que podría utilizarlas como alegato, cuando él es el querido [del demandante]. Y Él ha producido la expresión el ser humano, con el artículo al- [de al-insān], y el atractivo cautivador con el objetivo de incluir a la gente en gene$\mathrm{ral}^{38}$. Todo esto muestra que el deseo del Verdadero para todos ellos es que alcancen la felicidad en su destino final, incluso si Él les concede todo aquello que es contrario a la felicidad. ${ }^{39}$

34 C. $24: 31$.

35 Tāba, cf., tawba.

36 C. 9:118.

37 Varios comentaristas han debatido el porqué en este verso aparece "Señor" seguido de "más Generoso": birabbi-ka l- karīm (G. 82:6). Ibn Ğawzī, en su comentario de "¿Qué te ha cautivado de vuestro Señor, el karīm?", dice: "Se dice que, como Él menciona aquí el atributo, que es la generosidad magnánima (karam), dejando a un lado el resto de Sus atributos, es como si Él estuviese amaestrando (laqqana) a Su criatura con la respuesta correcta, para que la criatura pueda responder: "¡Lo que me cautivó fue el karam del Más Generoso (al-karim)!".

38 El engaño cautivador es universal, no solo el engaño de Satanás, y Dū l-Nūn al-Mișrī responde al verso así: "Cuántos son engañados por el sitr, y no se dan cuenta". Por otro lado, Qurțūbī cita una conexión entre karìm y sattār.

39 Es decir, a pesar de que a algunos se les conceda el Fuego en vez del Jardín de la felicidad, Ibn al-'Arabī argumenta que el Fuego se convertirá en felicidad. El 'ádāb (el tormento) de los desgraciados se convertirá en 'ádb (dulzura). 


\section{Muğăhada, combate}

Capítulo 765, 105.10-18

Como la destrucción de la sangre del corazón es el mayor sufrimiento para las almas, es conocida como ğihād. El alma está formada por dos almas: un alma que es deseosa de la vida de este mundo por su familiaridad con él; de este modo, este alma no quiere separarse y sentir ese sufrimiento. Por otro lado, un alma deseosa de una vida longeva en este mundo para, de esa manera, aumentar la obediencia [a Dios] y la conducta que le acerca a Él, así como la ma rifa o conocimiento divino y la ascensión perpetua con cada respiración. Por consiguiente, la separación de la vida de este mundo es dolorosa [para ambas almas]. Debido a esto, se la conoce como ğihād en relación a las dos tribus. En cuanto a los muğăhidūn en el camino de Dios, que es el camino hacia Dios, es decir, a la conexión con Él. Por esta razón, es una ğihāa a fin de obtener ma rifa del paso de nivel del que emerge el universo, y las principales propiedades en esto, y para el paso de nivel, son "las que están detrás de nuestros actos" en la Tierra. Así, a lo largo de estos caminos, ellos reciben el mismo dolor que el miedo que reciben los viajeros durante sus viajes, porque ellos van por un camino en el que se exponen a sí mismos al peligro a lo largo de la ruta de la destrucción de sus riquezas y almas, y sus hijos se convierten en huérfanos y pierden sus comodidades familiares. Él, alabado sea, dice: "Y se pelean con sus riquezas y con ellos mismos a lo largo del camino de Dios" ${ }^{40}$; Él también dijo: "Ellos luchan a lo largo del camino de Dios, y ellos matan y son asesinados". ${ }^{41}$

\section{Hulwa, retiro}

Capítulo 78, 5:115.7-116.1

Saber que Dios nos conduzca al éxito a nosotros y a ti, que el origen de hulwa en la revelación es: $E l$ que Me recuerda en su propio ser, yo lo recuerdo en Mí mismo, y el que Me recuerda en una reunión, yo lo recuerdo en una reunión mejor. Esto es un auténtico hadiz divino, que incluye los términos hulwa y ğulwa $a^{42}$. La raíz de hulwa viene de hallā el vacío, donde se crea el cosmos.

El que queda vacío y no se encuentra (usa el término wruğūd), no está vacío, sino que es un camino cuya propiedad se ha desgastado.

El Mensajero de Dios - la paz y las bendiciones sean con él- dijo: Dios es, y nada hay con Él. Y se le hizo la siguiente pregunta al Enviado de Dios: ¿Dónde estaba nuestro Señor antes de que Él creara Su

40 C. $8: 72$.

41 C. 9:111.

42 Ğulwa es el presumir de la novia ante su novio, como en ğalā al- urūs. En el Sufismo, los amantes de Dios son la novia y sus "muertes" son conocidas como sus bodas o 'urs. 
creación? Él respondió: Él estaba en una Nube, sin aire arriba y sin aire debajo. Entonces Él creó la creación y decretó y puso fin a las cosas; "y Él está cada día sobre un brillo radiante" ${ }^{33}$ y "Él pondrá fin a las cosas" ${ }^{\prime 4}$, y poblará después los lugares radiantes con su gente, para siempre.

Hulwa es la estación más alta, un lugar radiante que la humanidad poblará y llenará por completo con su ser, por lo que no cabe nadie más allí junto a la humanidad. Esta hulwa, y su relación con Él y viceversa, es la relación del Verdadero con el corazón de la criatura que es "lo suficientemente amplio" para acogerlo a Él. Él no entrará allí mientras haya otro en el corazón, desde cualquier perspectiva existencial. El corazón debería quedar vacío de seres existentes, todos y cada uno de ellos, para que Él apareciera allí de forma visible [116] con Su dāt. La relación del corazón con el Verdadero se basa en que fue creado "a Su imagen", por lo que no cabe nadie excepto Él.

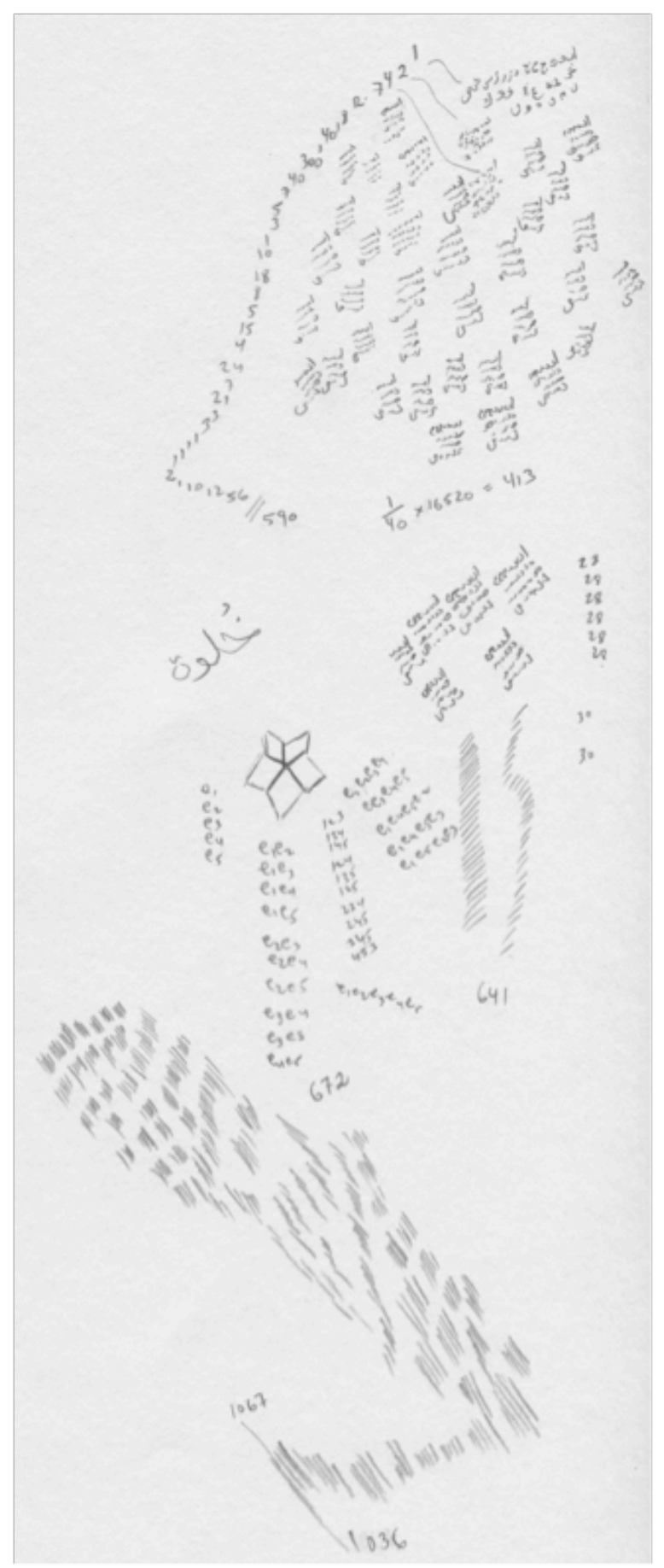

43 C. 55:29.

44 C. $55: 31$. 


\section{'Azl, aislamiento}

Capítulo 80, 5:122.8-12

Nadie se abstiene excepto aquellos que se reconocen a ellos mismos, y "aquellos que se reconocen a ellos mismos reconocen también a su Señor"; de este modo, no hay testigo más que Dios con respecto a Sus sutiles nombres, y ellos aceptan los nombres de forma visible e invisible. Sus nombres sutiles, que lo glorifican más, se dividen en dos categorías. En primer lugar, los nombres [1] que el intelecto puede recibir y puede, independientemente, percibir, asignar, y por los cuales puede llamar a Dios glorificado sea. En segundo lugar, aquellos nombres que son divinos, pero de no ser por el advenimiento de la Ley que los transmite no serían aceptados. Sin embargo, la fe los recibe y uno no piensa en ellos de modo inteligible con respecto a $\mathrm{Su} \underline{d} \bar{a} t$, a menos que el Verdadero te informe de cómo comprobar por uno mismo la correlación de estos nombres con Él, así como Él se los enseñó a Sus profetas y amigos (awliy $\bar{a})$.

\section{$5: 123.7-10$}

... nombres como 'El que ríe', 'El que se regocija', 'El que se maravilla', 'El que ama', 'El Indeciso', 'El que se siente degradado', 'El que olvida', 'El poderoso y otros semejantes a aquellos citados en el Libro y en la Sunna ${ }^{45}$, hasta las

45 Por ejemplo, “¿Acaso ríe el Señor? Él dice: Sí. Yo digo: No nos faltará ningún bien de un Señor que ríe"; "Dios se regocija en el arrepentimiento de uno de vosotros más aún de lo que vosotros os regocijáis cuando encontráis a vuestro animal perdido"; "Nuestro Señor se asombra con el hombre que combate en el camino de Dios, sus compañeros aunque abandonen, pero él sabe lo que tiene que hacer, así que regresa hasta que su sangre se derrama"; "De hecho, Dios es paciente, le gusta ser paciente en todos los aspec-

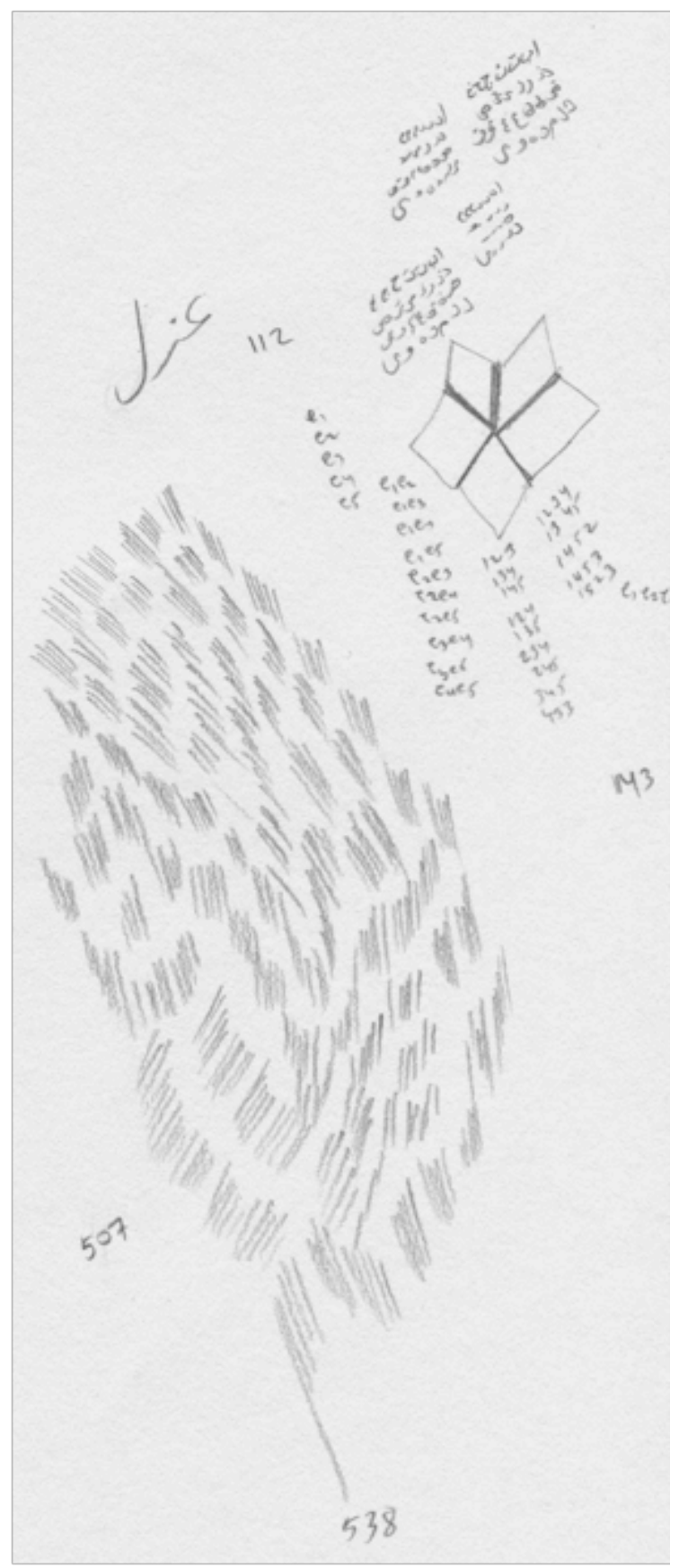


configuraciones fisicas inclusive, tales como las menciones de "mano", "dos manos" y "manos"; y "pie", "ojo", y "ojos"46, hasta las configuraciones de estados físicos inclusive, tales como "sentarse" [en el Trono], estar [contigo dondequiera que estés], descender [en la tercera parte de la noche], así como buscar, desear, y declaraciones como éstas.

\section{Fireār, huída}

Capítulo 82, 5:131.18-132.5

Cada nombre Divino quiere anclarte y amarrarte a él, y que seas una aparición visible de su dominio sobre ti. Pero tú, tú ya sabes que tu felicidad está en exceso, y no serás feliz a menos que te desplaces a la norma de otro nombre, donde te beneficiarás [132] de cierta información que no habías tenido antes. Pero el nombre en el que te encuentras no te dejará marchar. Por lo tanto, estás obligado expresamente a huir, y la advertencia [del que te advierte con su aclaración] es que el nombre en el que te hallas no debería tener poder sobre ti para continuar a tu lado; de este modo huyes hacia un lugar de abundancia. Mismamente, la huida es una propiedad que acompaña a la criatura en este mundo y en el siguiente. Y son 512

tos"; "Yo no dudo como dudo al acoger el alma del creyente que odia la muerte"; "A quien le desagrade reunirse junto a Mí, a mí me desagradará reunirme con él"; "Ellos olvidan a Dios, por lo que Él los olvida a ellos"; y "Él dice: Por supuesto, pero cuando él lo negó, sentí tanta vergüenza ajena, que debí de haber llamado mentira a su barba blanca [metonimia para un comportamiento digno]".

46 Por ejemplo, "La mano de Dios está con el grupo"; "Las dos manos de Dios son Derechas"; bi-aydin (G. 51:46]; "El Controlador pondrá su pie en el Yahannam"; 'alā 'aynī (C. 20:39).

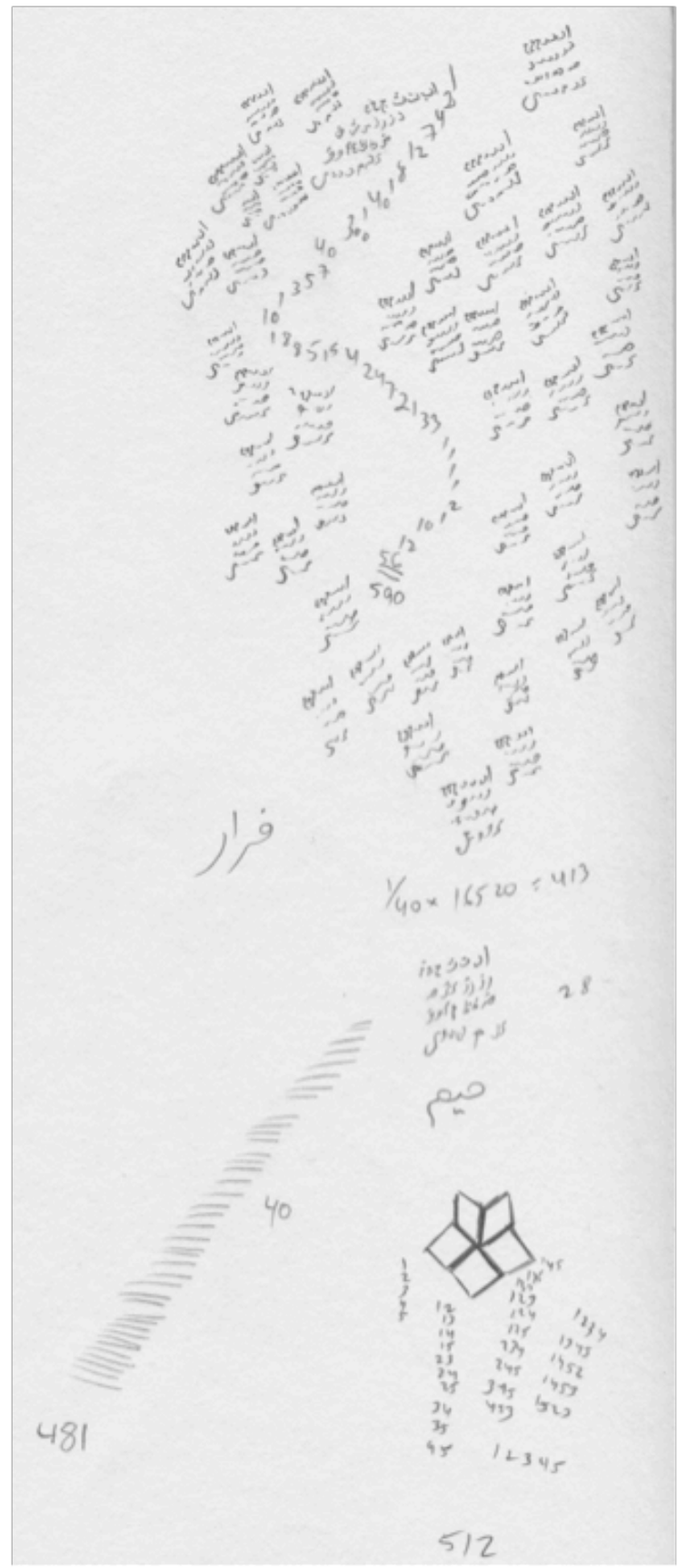


los grados del 'arifiùn entre la gente de intimidad y conexión, los mismos grados que hay entre la gente de cortesía que se detiene [ante los límites]. Y son 481 los grados del malāmīya entre la gente de intimidad y conexión, los mismos grados que hay entre la gente de cortesía y que se detiene ante los límites.

\section{$\operatorname{Qanā}^{c} a$, satisfacción/ruego}

Capítulo 116, 5:264.13-18

La palabra qanā $a$, para nosotros, se encuentra dentro del contexto del lenguaje, y significa pedir, y "aquel que es qanā' $a$ " es aquel que suplica, y el pedir le corresponde a Dios, no a nadie más ${ }^{47}$. Tú dices qani'a [tercera persona, masculino, singular, perfectivo], yaqna $u$ [imperfectivo], qanū'an [adjetivo] cuando alguien suplica. Es aquel que eleva su súplica a Dios, y esta es Su palabra referente a los opresores en el día del Juicio, "aquellos cuyas caras se elevan (muqni î) en súplica"48; es decir, elevadas hacia Dios, rogándole que pase por alto sus crímenes. Las dos definiciones [que son antónimos] se combinan en una situación, en la que los defensores son qan $\bar{u}$ con Dios, es decir, están muy satisfechos con Él en sus súplicas y en sus peticiones a Él, sea alabado. Éste es el significado de la declaración de los grandes maestros, en su definición de qanā'a): estar "muy satisfecho ${ }^{49}$ con lo que es (marğ̌̆d $)$," y esto es Dios; [muy satisfecho] "al pedirle [a Él] en procura de

47 Lisān al-'arab anota que la palabra es su propio antónimo, y ambas significan "ser suficiente con" y "suplicar por".

48 (C. 14:43).

49 Lane anota, inna fì d̄ālika la-maqna'an, Ciertamente, hay autosuficiencia en esto.

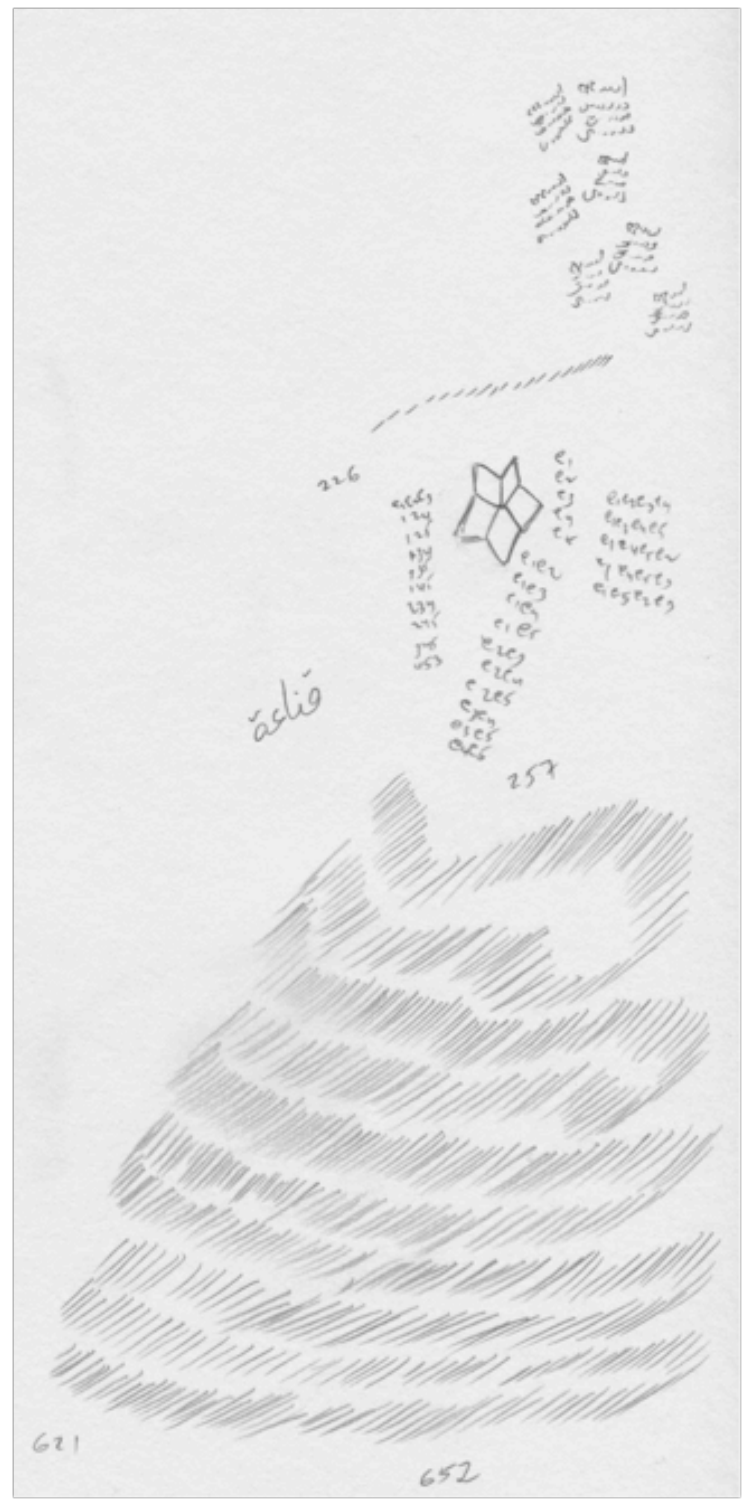

lo mejor", de modo que nos se transgredan los límites pidiendo a otro que no sea Dios. 


\section{Šarah y hirs, servor y ansia}

Capítulo 117, 5:267.2-5

Consideremos ahora, junto a lo anterior, šarah (fervor) y hirs (ansia), que son dos de las cualidades de aquel que sabe, aquel que hereda [de los profetas], aquel que llega a ser completo, aquel que es el administrador de una comunidad. Buscan lo que sería una mejora para su comunidad, tal y como Él dijo acerca de Su profeta - la paz y las bendiciones sean con él-, alabándolo: "Él está ardientemente deseoso de ti” ${ }^{\prime 50}$. De este modo Él lo alabó por tener hirs con respecto a aquello que ayudaría a su comunidad. Su fervor y su ansia correspondían a la sumisión al Islam de su tío Abū Ṭālib, hasta tal punto que le dijo: "Susurra [el testimonio del Islam] en mi oreja para que pueda testificar en tu nombre que tú lo has dicho", basándose en el conocimiento de que su testimonio sería aceptado, y en que sus buenas palabras serían escuchadas [por Dios en el Día del Juicio].

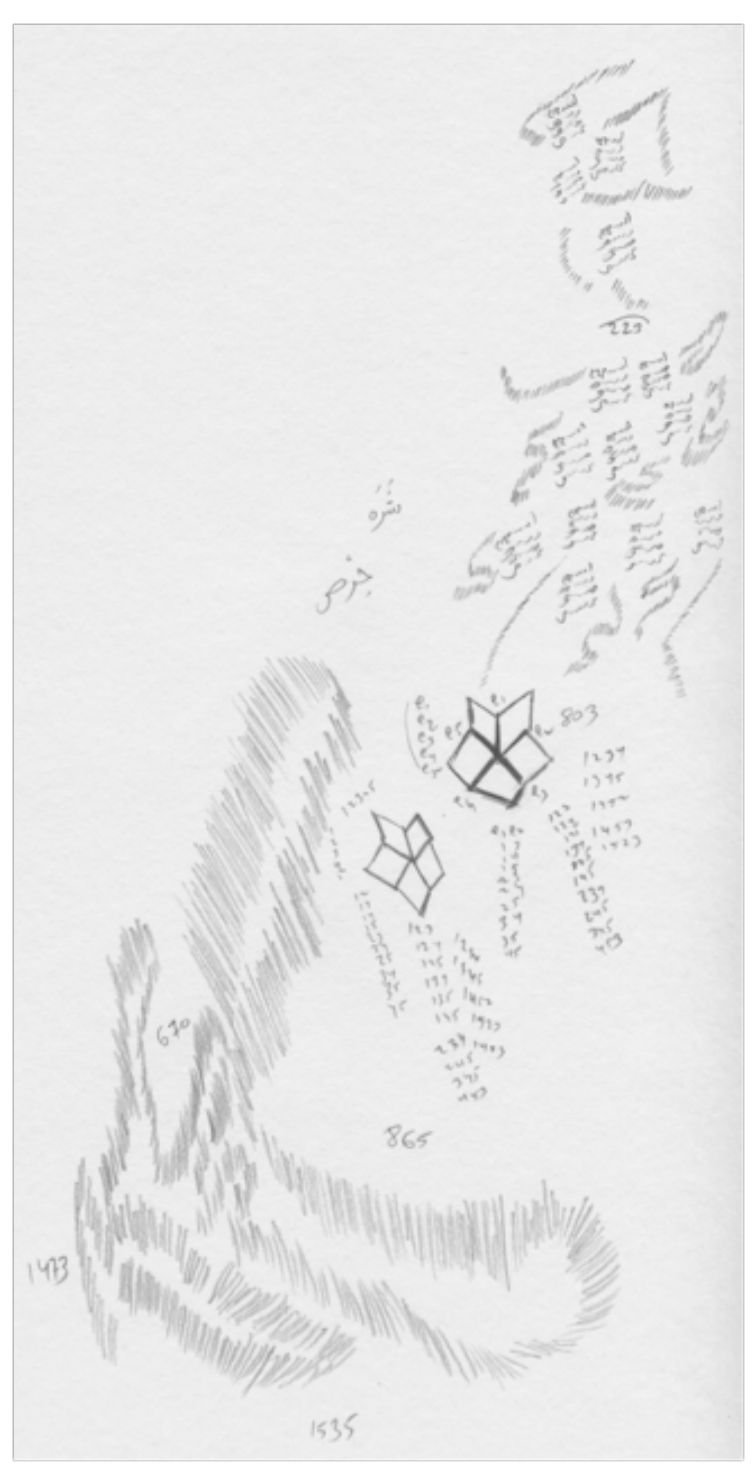

50 C. 9:128. 


\section{Tareakkul, confianza}

Capítulo 118, 5:269.6-7

Tawakkul es la tendencia de apoyar el corazón en Dios, alabado sea, sin desesperanza tras la pérdida de los recursos secundarios dispuestos [como ley natural] en el mundo, aquellos recursos donde buscan apoyo las almas para sus ocupaciones, ya que si hay desesperanza, no serás alguien de tawakkul.

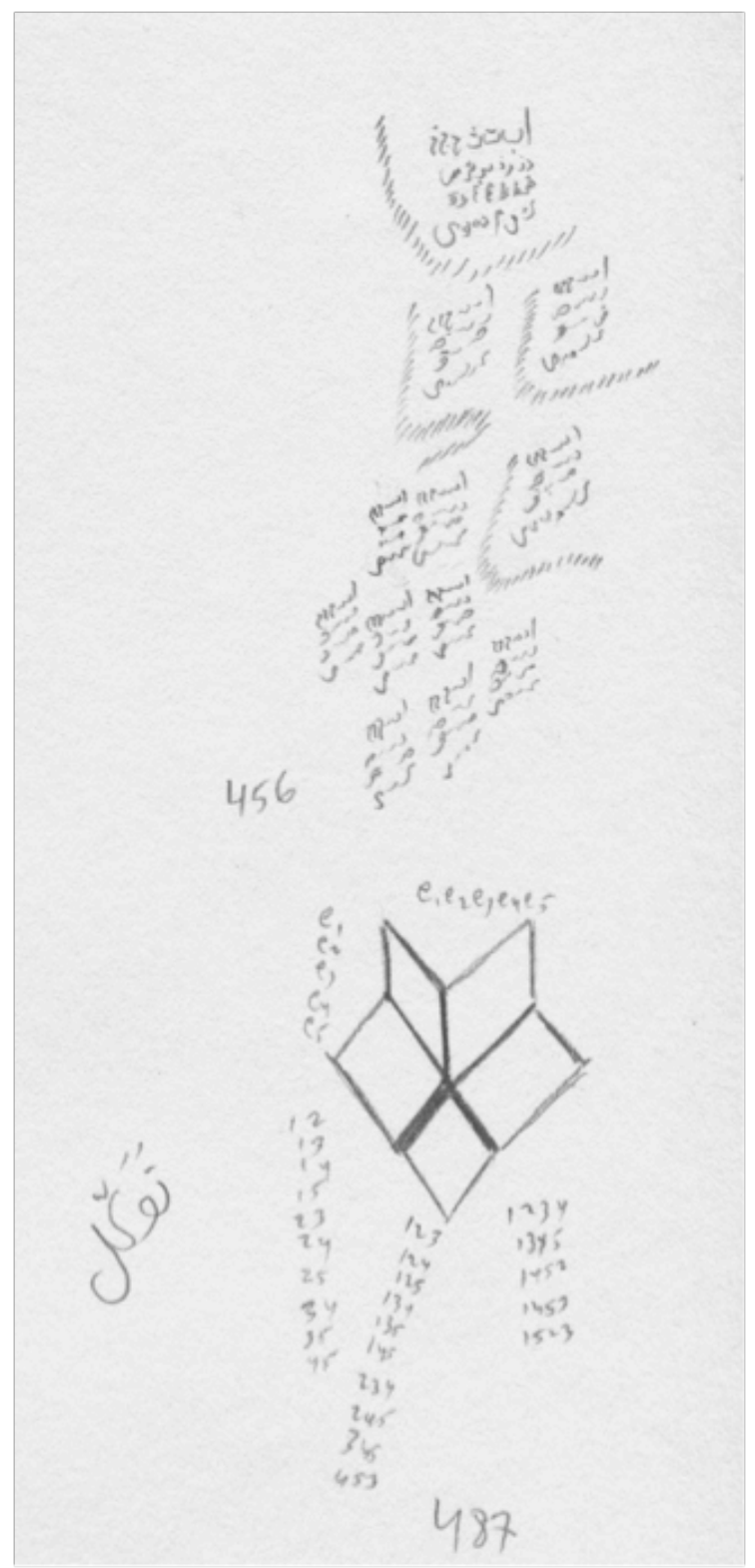




\section{Šukr, gratitud}

Capítulo 120, 5:276.16-277.6

Considera detenidamente la correlación de la "gratitud" con Él, alabado, cuando usa la forma gramatical de intensidad [es decir, fa ûl, šakūr] con respecto a la persona que actúa bien con respecto a Él con todos sus miembros y facultades, externamente [visibles] e internamente [invisibles], durante cada estado ${ }^{51}$ según sea apropiado y en cada momento según corresponda. Así, el Verdadero agradece todo ello por medio del nombre Él profundamente Agradecido (al-šakūr), y esta es una de las particularidades de la gente de Dios. Acerca de la gente común, la situación está por debajo de este nivel con respecto a las acciones en el estado [las suyas no se dan "durante cada estado"] y durante el periodo de tiempo [las suyas no se dan "durante cada periodo de tiempo" ${ }^{52}$. Cuando traen una acción con esta definición de inferioridad, les corresponde el nombre [Divino] šākir ('El que agradece'), no šakūr ('El profundamente agradecido'). Ellos son en cada estado los agradecidos. Pero Dios, alabado sea, dijo: "Y algunas de Mis criaturas están profundamente agradecidas" ${ }^{\prime 3}$, y son los únicos elegidos por Dios porque son capaces de ver todo cuanto es como ser de Dios, con respecto a ellos y a Sus criaturas; todo lo ven como bendición divina tanto si les hace feliz como si les causa dolor; de este modo, ellos están agradecidos en cada momento [y estado]. Son pocos los de este tipo de personas, como sabemos por experiencia

51 Un estado puede ser "restrictivo", "enfermo" o "hambriento".

52 El Dr. Manșūb comenta: Añadido en el margen, de otra mano, aparece un signo de "correcto" y pone "y la combinación del todo".

53 C. 34:13.

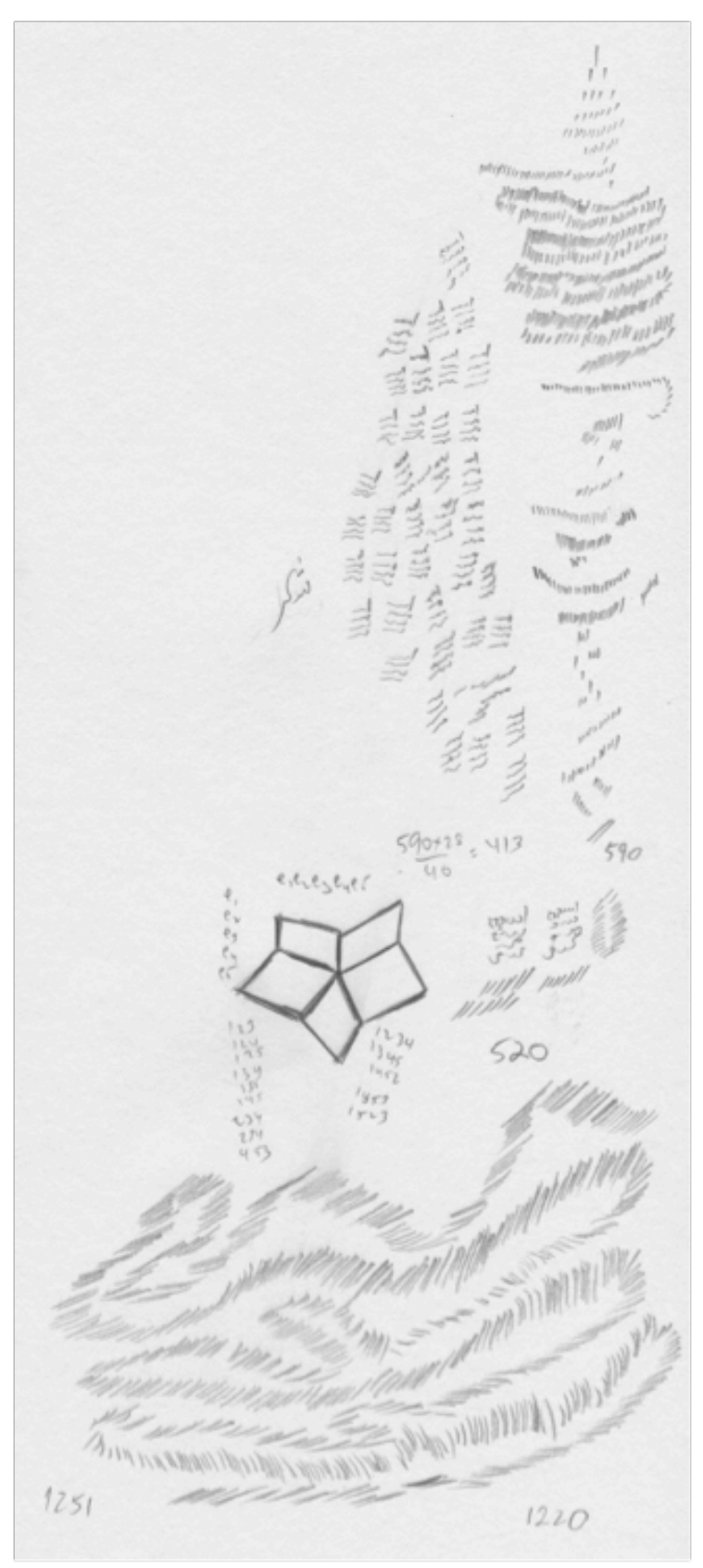

y por lo que Dios nos ha enseñado acerca de su escasez $^{54}$. Y en cuanto a aquellos que son agradecidos, de entre el común de las criaturas, son los que agradecen a Dios únicamente por lo que es reconocido de manera convencional como bendición.

$54 \mathrm{Al}$ igual que en C. 34:13. 


\section{Yaqin, certeza}

Capítulo 122, 5:283.6-13

Certeza es la palabra que Él utiliza para Su profeta -la paz y las bendiciones sean con él-: "Venera a tu Señor hasta que la certeza llegue a ti" ${ }^{\prime 55}$. Su propiedad es la tranquilidad del alma de aquel que se ha hecho seguro, o el movimiento del alma hacia esa seguridad. Es donde se encuentra el ser humano, situado sobre el conocimiento, conocimiento acerca de cualquier cosa. Dado que el objetivo propio del alma es llegar hasta allí, éste será, por lo tanto, la certeza, sin importar si se ha conseguido dicha certeza en el momento o no. Es como Sus palabras: "La situación de Dios se cumplirá" ${ }^{56}$. Incluso si no sucede inmediatamente después, el alma fiel sigue aun estando completamente convencida de que ese momento llegará, por lo que no existe diferencia para ella entre su llegada y su no-llegada: es el estado de aquel que dice, "Incluso si se quitaran los velos, yo no podría estar más seguro.” Esto ocurre a pesar del hecho de que aquello de lo que uno está seguro no se crea ante el ojo. Así Dios dijo a Su profeta y a cada criatura que se encontrase en esa posición: "Venera a tu Señor hasta que la certeza llegue a ti" ${ }^{57}$ Entonces, cuando la certeza llegue a ti, se conocerá quién ha venerado y quién ha sido venerado, quién está haciendo y para quién se está haciendo. Se conocerá exactamente cuál es el efecto de lo Manifestado en el lugar de la Manifestación, y lo que los lugares de la manifestación emergente proporcionan al Manifestado.

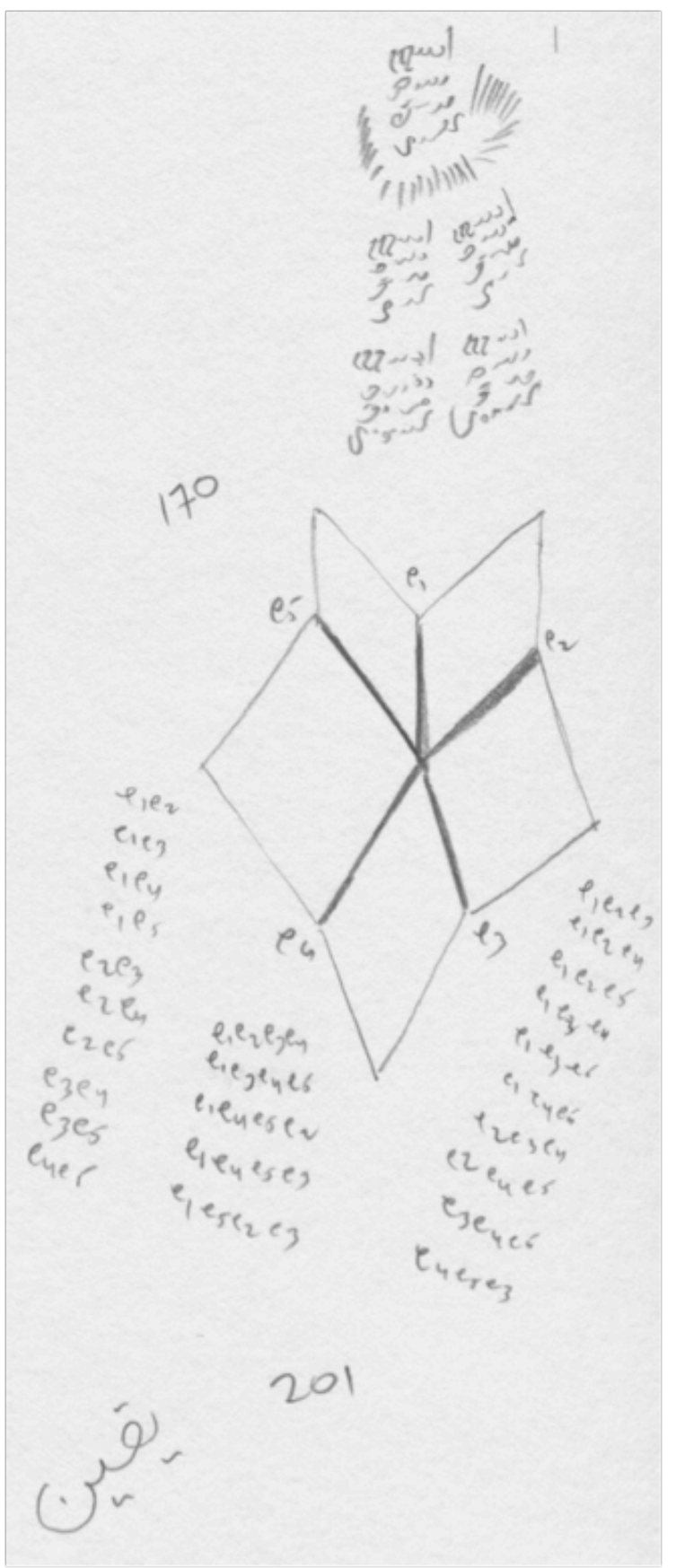

55 C. 15:99.

56 C. $16: 1$.

57 C. 15:99. 


\section{Sabr, paciencia}

Capítulo 124, 289.1-12

Y Su bondad se impone ante Su ira. Así, la sabiduría de hacer desaparecer este mundo hace que se desvanezca el enfado (adan) [atribuido a] Dios; de hecho, el enfado solo existe en este mundo. Por lo tanto, dad buenas nuevas, criaturas de Dios, de todo lo que encierre bondad, de su gran difusión, y de la nube que cubre todo lo creado excepto a Dios. Hacedlo, aunque haya pasado un tiempo, porque con la desaparición de este mundo, el enfado desaparece de todo aquel que estaba preocupado, y eliminado el enfado, ya no es necesario ser paciente. El enfado (adan) es uno de los medios por los cuales ocurre el castigo, pero [en el otro mundo] los problemas han desaparecido. Es entonces cuando verdaderamente existe la bondad [que lo abarca todo] y desaparece el enfado, y es también cuando existe la bondad que es universal sobre todo lo relacionado con la gracia de Dios, si Dios quiere. Este es nuestro juicio acerca de Dios, porque Dios, y es Él quien dice la Verdad, afirma: Yo soy según el juicio que Mis criaturas tienen de Mí, así que dejad que me juzguen para que sea Bueno. Por lo que Él comunicó [esta declaración] y Él ordenó [a Sus criaturas que lo consideren Bondadoso]. Él no puso ninguna condición con respecto a su "juicio", ni respecto a ninguna otra cosa. Debido a esto, lo que nosotros conocemos como un tormento ('ádāb) que causa dolor es, en realidad, una buena nueva de Dios para Sus criaturas; de hecho, aquello que les causará sufrimiento, ciertamente, [habrá dolor en el Fuego], [se transformará entonces] cuando la bondad te envuelva por completo, y sentirás la dulzura [tasta bid de la misma raíz que 'ádāb], incluso mientras estés en el Fuego. Es como si la persona fría encontrase dulzura en el calor del fuego, y la persona ardiente encontrase dulzura en el frío y en el hielo. Por este motivo, el Ğahannam combina fuego y frío hielo, debido a las diferentes constituciones [de modo que cada constitución escoja lo que mejor se adecúe a ella]. Así, el dolor ocasionado a una determinada constitución provoca placer a otra constitución [que es su opuesta]. De esa manera, la sabiduría no se equivoca [y cada opuesto se puede utilizar para el efecto de lo Bueno]. Y Dios conserva para la gente del Ğahannam el frío hielo para quienes son excesivamente calientes, y el fuego para quienes son fríos. Así, ellos serán bendecidos en el Ğahannam; ciertamente, son de tal constitución, que si tuvieran que entrar al Jardín [del paraíso] con dicha constitución, serían atormentados por su temperatura moderada. 


\section{Murāqaba, conciencia}

Capítulo 126, 294.3-16

Se consciente de Él a cada momento radiante y brillante, como Él, más que alabado sea, lo es de ti,

Durante su presencia y ausencia, debidas al brillo parpadeante. A causa de este parpadeo, yo tengo, durante cada momento que pasa, una participación de gracia.

Entonces, cuando el momento clave llegue y acabe conmigo, no lo tendré en cuenta. ¡No es esto asombroso!

La conciencia atenta (murāqaba) es una categoría divina de la que obtenemos un trago (una parte de una bebida, širb). Él, alabado sea, dijo: "Dios está por encima de todo observándolo atentamente"58; y estas son Sus palabras: y "a Él no le resulta onerosa su conservación y cuidado" 59 , refiriéndose a los Cielos (el mundo superior) y la Tierra (el mundo inferior). Solo existe el superior y el inferior, aunque el mundo [también] se divide en dos partes: un mundo que sustenta por sí mismo, y otro que no. El mundo que se sustenta por sí mismo consta de átomos inorgánicos y cuerpos orgánicos, y el mundo que no se sustenta por sí mismo consta de distintas formas y una variedad de colores, y son variedades y cualidades adjetivas ${ }^{60}$. El mundo de los cuerpos orgánicos y los átomos inorgánicos no tiene permanencia a menos que haya una interación entre los dos [Cielos y Tierra]; de este modo, cuando la interacción no se dé entre los dos (aquella a través de la cual los átomos y cuerpos pueden persistir y existir), los átomos y cuerpos serán anulados. ${ }^{61}$

Y no hay duda de que las variedades llegan a ser anuladas en el segundo periodo de tiempo tras el periodo de tiempo de su ser inicial ${ }^{62}$. Así, el Verdadero nunca deja de supervisar y preservar el mundo de

58 C. $33: 52$.

59 C. $2: 255$.

60 Estos son las variedades de colores, como el color amarillo, que no se sostiene por sí solo; algo que se sostiene por sí solo puede asumir la amarillez no permanente, transitoria, como una varietad.

61 Partiendo del principio "El mejor de los mundos posibles" de Leibniz, los físicos Julian Barbour y Lee Smolin desarrollan un proceso de "variación extrema" en el que se describe cómo pudo haberse creado el universo, teniendo en cuenta el principio de que cada partícula debe ser totalmente distinta a cada partícula que la rodee. Mostraron cómo la estructura de lo atómico puede elevarse a lo cósmico simplemente con este proceso. Respecto a eso, Ibn al-'Arabī afirma que cada partícula que en un supuesto se sostiene por sí misma, en realidad, solo existe y persiste cuando una interacción lo llena de color; cuando ese color desaparece, la partícula desaparece.

62 No hay "duda" de que las variedades desaparecen de forma instantánea, que es la definición filosófica analítica de su naturaleza; pero Ibn al-'Arabī añade que los átomos y cuerpos (que parecen ser "esenciales" y "sustanciales") también desaparecen de forma instantánea. Se trata de la Nueva Creación (C. 50:15) que da vida a cada periodo de tiempo significativo (zaman far), "cada aliento", que puede ser un periodo medido en femtosegundos o segundos de Planck (dado que cada partícula del sistema solar se ilumina individualmente durante cada "día" de la creación). Véase "Time is not real", Fournal of the Muhyiddin Ibn Arabi Society 51 (2012) 
os cuerpos orgánicos y los átomos inorgánicos, el superior y el inferior; tantas veces como Él anula un 'arad ${ }^{63}$ de ellos, durante el cual se produce su ser, Él crea en dicho periodo de tiempo un 'arad similar u opuesto, evitando así que sea anulado, durante cada periodo de tiempo. Él siempre está creando, y el mundo depende de Él, alabado sea, por siempre jamás, con una dependencia esencial, tanto del mundo de las variedades como de los átomos. Por lo tanto, este es la vigilancia atonta que tiene el Verdadero sobre Su creación, con el fin de garantizar su existencia. Estos son los brillos parpadeantes expresados en Su Libro cuando dice que Su ser está cada día sobre un brillo radiante. ${ }^{64}$

\section{Sidq, veracidad}

Capítulo 137, 338.14-17

Y sidq es una correlación que no tiene entidad global, sino grados, y son 195 los grados para los 'ärifün de entre las personas de los misterios, 225 los grados para los 'ārifün de entre las personas de las luces, 164 los grados para los malāmìya entre las personas de los misterios, y 194 los grados para los malämīya entre las personas de las luces.

A continuación, os proporciono una raíz uniforme para todo lo que he citado acerca de abandonar todo lo que hemos establecido; de hecho, con esto quiero decir, "abandonar el propio testimonio," sin abandonar la huella de su efecto, debido a su propiedad; y no es posible decir acerca de ello que no es, ya que es algo concreto (mawğūd $)$, presenciado por todo ojo. Basándonos en lo anterior, tomad en cuenta cada palabra de lo que he mencionado en este libro sobre el abandono; aprended pues esto.

y "Gut bacteria", JMIAS 54 (2013).

$63 \mathrm{El}$ 'arad es un término empleado por los teólogos (al-mutakallimūn) que significa "algo que no tiene permanencia", "un accidente" (Lane). Ibn al-'Arabī ha hablado con aprobación de la posición Aš́arī y de que el 'arad desaparece en cada caso y no tiene permanencia, en otras palabras, que todo es creado de nuevo en cada caso. Pero mientras los filósofos discuten si el 'arad es una interacción aleatoria, como la "amarillez" que tiñe a una sustancia, Ibn al-'Arabī observa la variedad y el átomo sustancial que es fugaz y no permanente. Además, Ibn al-'Arabī emplea la palabra en su campo semántico más amplio, como en a rada laka l-šay'min ba îd, La cosa se te apareció desde lejos (Lane). Más adelante, en este mismo capítulo, Ibn al-'Arabī cita el hadiz, que en otras versiones comienza así: úridat li, "Se presentó ante mí el muro entre (urd) el Jardín y el Fuego". El 'arad es la presentación de un "mundo", tanto si es insustancial ("no se sostiene por sí mismo", como la discusión del Ašcart) como sustancial ("se sostiene por sí mismo", ambos son para Ibn al-'Arabī completamente dependientes del ser de Dios y Sus nombres para su presentación y existencia. La progresión temporal (que es totalmente inaccesible para la percepción de la creación) es: desde la partícula $n_{1}$, hasta la $t_{1}$, llegando a ser la $t_{2}$ una partícula $n_{2}$, que es similar o contraria a la $n_{\text {l. }}$.

64 "De Él todo en los Cielos y la Tierra procura [su ser]; cada día [hasta el período de tiempo más pequeño] Él está sobre un brillo radiante [proveyéndoles su ser]" (C. 55: 29). 


\section{Hay $\overline{\boldsymbol{a}}$, pudor}

Capítulo 138, 340.12-18

En el texto queda constancia de que habrá un šayh en el Día del Juicio, Dios le dijo: "Oh Mi criatura, tú hiciste esto y aquello", cosas que no era apropiado hacer. La criatura respondió: "¡Oh mi Señor! Yo no lo hice". Pero sí lo había hecho. Entonces el Verdadero dijo: "Llevadlo al [lugar que le corresponde en el] Jardín." Los ángeles, los únicos que dan cuenta de sus actos (y asignan su correspondiente lugar), dijeron: “¡nuestro Señor! ¿Acaso no sabes que él sí hizo esto y aquello?” Él respondió: "Por supuesto, pero cuando él me lo negó, sentí vergüenza ajena a la hora de llamar mentira a su barba blanca [metonimia para un comportamiento digno]". Por lo tanto, si Dios se avergüenza ante la criatura y se contiene de llamar mentira a su barba blanca, y lo honra, es entonces aún más apropiado para la criatura que tenga esta cualidad.

La disculpa debida al pudor tiene grados con los 'ārifün y con los malāmīya. Sus grados para los 'ārifūn son 51, y para los malāmīya son 20. Dios dice la verdad y es el guía por el camino.

\section{Tark al-hurrīya, abandono de la libertad}

Capítulo 141, 350.9-17

El Mensajero de Dios -la paz y las bendiciones sean con él- dijo a Abū Bakr al-Ṣiddīq: “¿Por qué sales?". Él respondió: "Oh Mensajero de Dios, por el hambre”. El Mensajero de Dios -la paz y las bendiciones sean con él- respondió: "Yo también, el hambre ha hecho que salga". Entonces, se dirigió con alguien que lo acompañaba, uno de sus compañeros, a la casa de Haytam ibn Abī l-Tīhān, y este hizo un sacrificio (de un animal) para ellos y les dio de comer. Así que, lo que les hizo salir [de sus casas] fue alguien que tenía poder sobre ellos cuando giró su rostro hacia la dirección donde ellos se encontraban, y era el hambre. El hambre es algo vacío. Algo concreto tiene un efecto en algo vacío: ¿Cuál es la situación con la presencia de algo concreto? Una alegoría para aquellos que tienen una visión de la libertad [por ejemplo, el liberarse del hambre], y para este punto de vista, podría ser: ellos salen [de sus casas] únicamente para buscar la manera de satisfacer el derecho que les correspondía [es decir, el ser alimentados]. De ese modo, el hambre los esclavizó, y de no haber salido, y haberse mantenido en calma, habrían sido forzados completamente por la paciencia, un estado que no se busca. Así, la máxima correlación de bondad hacia ellos es que ellos debían salir [tal y como dijimos] en una búsqueda de cómo conseguir el derecho que les correspondía, corriendo [como en el są de Hağar corriendo en busca de agua para su hijo], ya que ellos tenían el poder para hacerlo. No existe nada por encima de esto, porque si se hubiesen quedado sentados a pesar de poseer ese poder, hubieran sido acusados de ser opresivos (con sus almas) y de ignorar la decisión divina. Así que, ¿qué opinas acerca de la libertad de alguien que tiene dicha cualidad en este mundo y en el siguiente? 


\section{Dikr, recuerdo}

Capítulo 142, 353.15-354-5

El Profeta - la paz y las bendiciones sean con él- dijo: El momento no llegará hasta que no quede nadie sobre la faz de la Tierra que diga, Dios, Dios, y no definió otra situación a parte de esta expresión [Dios, Dios], porque es un $\underline{d} i k r$ especial para Sus criaturas, mediante las cuales Dios preserva el universo de este mundo, así como cada morada que hay en él. De este modo, cuando no quede en este mundo resto alguno de ellos, Dios no tendrá ninguna razón para seguir preservando este mundo. Entonces desaparecerá y se desintegrará. Guántos dirán 'Dios' en aquel momento, pero no serán de los que recuerdan $(\underline{d} \bar{a} k i r)$ que hacen presente lo mencionado anteriormente. Por esta razón, la expresión no se expresa independientemente, sino junto a hacer presente. [354] "Y cuando recordéis a vuestro Señor en el Corán, solo a Él, volverán sus espaldas y huirán” ${ }^{65}$, porque no escuchaban ningún recuerdo de sus ídolos, por lo que sus corazones se encogieron, aun sabiendo que fueron ellos los que establecieron a los ídolos como dioses. Por este motivo, Él dijo: "Decid: ¡Nombradlos!”"66, porque si ellos sí los nombran, la palabra final irá contra ellos ${ }^{67}$. Así, nadie es llamado Dios sino Dios. Y los grados del dikr con los 'àrifün entre las personas de Dios son 951, y 920 grados con los malāmīya.

\section{CONGLUSIÓN}

El primer público de Ibn al-'Arabī habría estado familiarizado con los músicos callejeros que tocaban alrededor de las tumbas de los santos para el urs, el festival de los santos, dibujando diseños extravagantes en la noche con barras luminosas. Él utiliza esta imagen, en la que nunca se ven las ascuas, ya que solo se aprecia la imagen, para ilustrar el tema central de Futūhāt: las ascuas nos representan a nosotros, y a cada partícula en la creación, que somos lugares de manifestación, lugares de una

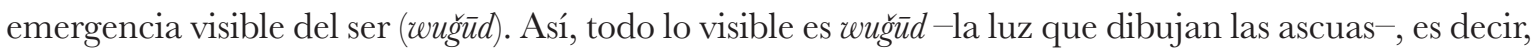
sólo Dios es, y sólo Dios es visible.

Siglos más tarde, Picasso pintó estas imágenes como fotografiadas, imágenes trazadas con luz; con Man Ray, este concepto nos llevó a la fotografía moderna. En la actualidad, muchas sociedades son hipervisuales, y el folioscopio y la película (con marcos que son invisibles, donde solo son visibles las imágenes que pasan a una velocidad mayor a 15 fps) son cautivadoras ilustraciones de la visión de Ibn al-'Arabī.

65 C. 17:46.

66 C. 13:33.

67 Es decir, ellos no dirán "Éstos son trozos de madera o piedras" que ellos están alabando, sino "Esto es Dios". Y cuando nombren (a esas cosas) como Dios, la situación se volverá contra ellos porque Dios no autorizó - a través de un mensajero- a que se alabara de esa manera. 

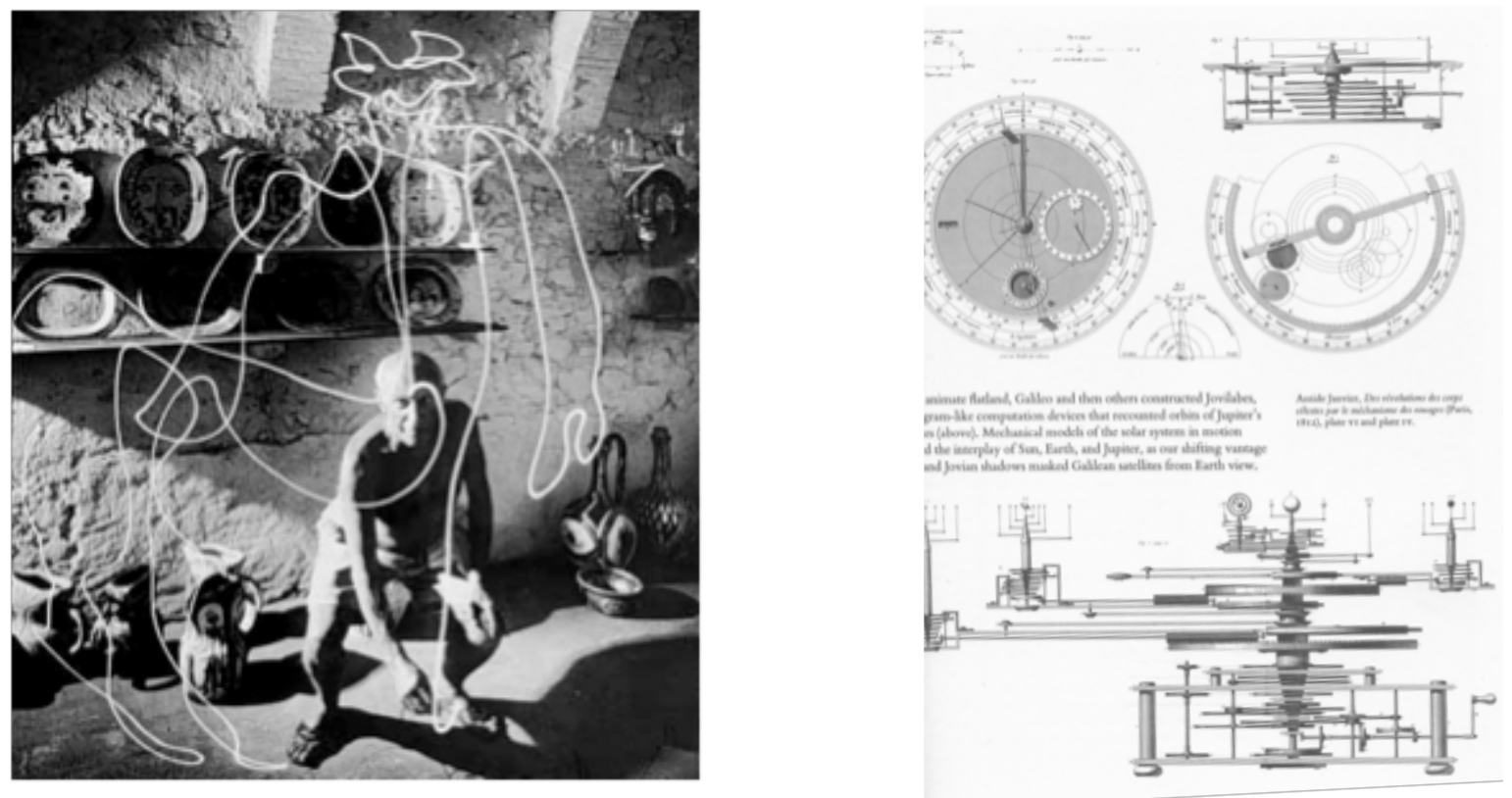

Antide Janvier, Des révolutions des corps célestes par le méhanisme des rouages, París, 1812, Edward R. Tufte, Envisioning Information, Graphics Press, Connecticut 1999, p. 99.

Recientemente hemos visto que una de las formas más efectivas de expresar las realidades de la visión de Ibn al-'Arabī y el camino místico es a través de las películas, como en la obra de Nacer Khemir.

Del mismo modo, debemos considerar el impacto del Liber Abici ("Libro del ábaco") de Leonardo de Pisa (Finonacci), ambientado en la ciudad portuaria de Bujía, cuyo santo patrón fue Abū Madyan, maestro de Ibn al-'Arabī. La habilidad de manipular los números indo-arábigos parecía algo mágico para las personas que únicamente conocían los números romanos. Siglos después, muchas sociedades están preparadas para entender dimensiones superiores y complicadas estructuras usando números y esquemas.

El número de grados que Ibn al-'Arabī menciona parecía estar claro en su mente, pero él era consciente de que el tamaño de Futūhāt, que alcanza unas 10.000 páginas, limitaba aquello que él podía pararse a describir. Mi intento de representar las estructuras de lo que he observado es una extensión de la misión de traducir y trasmitir la obra.

Traducción de María Mercedes Rubio Muñoz. 